\title{
Synthesis, Structural Analysis, and Biological Evaluation of Thioxoquinazoline Derivatives as Phosphodiesterase 7 Inhibitors
}

\author{
Tania Castaño ${ }^{\mathrm{a}}$, Huanchen Wang ${ }^{\mathrm{b}}$, Nuria E. Campilloa ${ }^{\mathrm{a}}$, Sara Ballester ${ }^{\mathrm{C}}$, Coral González- \\ García $^{\mathrm{C}}$, Javier Hernández ${ }^{\mathrm{C}}$, Concepción Pérez ${ }^{\mathrm{a}}$, Jimena Cuencad ${ }^{\mathrm{d}}$, Ana Pérez-Castillod, Ana \\ Martínez $^{\mathrm{a}}$, Oscar Huertas ${ }^{\mathrm{e}}$, José Luis Gelpíf ${ }^{\prime}$ F. Javier Luque ${ }^{\mathrm{e}}$, Hengming $\mathrm{Ke}^{\mathrm{b}}$, and Carmen \\ Gil $^{\star}, \mathrm{a}$ \\ aInstituto de Química Médica (CSIC), Juan de la Cierva 3, 28006 Madrid (Spain) \\ ${ }^{b}$ Department of Biochemistry and Biophysics and Lineberger Comprehensive Cancer Center, The \\ University of North Carolina, Chapel Hill, NC 27599-7260 (USA) \\ 'Unidad de Regulación Génica, CNM Instituto de Salud Carlos III, Madrid (Spain) \\ dInstituto de Investigaciones Biomédicas (CSIC-UAM) Arturo Duperier 4, 28029 Madrid (Spain) \\ eDepartamento de Fisicoquímica e Instituto de Biomedicina (IBUB) Facultad de Farmacia, \\ Universidad de Barcelona, Avda. Diagonal 643, 08028 Barcelona (Spain) \\ fDepartamento de Bioquímica y Biología Molecular Facultad de Bioquímica, Universidad de \\ Barcelona Avda. Diagonal 643, 08028 Barcelona (Spain)
}

\begin{abstract}
PDE7 inhibitors regulate pro-inflammatory and immune T-cell functions, and are a potentially novel class of drugs especially useful in the treatment of a wide variety of immune and inflammatory disorders. Starting from our lead family of thioxoquinazolines, we designed, synthesized, and characterized a novel series of thioxoquinazoline derivatives. Many of these compounds showed inhibitory potencies at sub-micromolar levels against the catalytic domain of PDE7A1 and at the micromolar level against PDE4D2. Cell-based studies showed that these compounds not only increased intracellular cAMP levels, but also had interesting anti-inflammatory properties within a therapeutic window. The in silico data predict that these compounds are capable of the crossing the blood-brain barrier. The X-ray crystal structure of the PDE7A1 catalytic domain in complex with compound $\mathbf{1 5}$ at a resolution of $2.4 \AA$ demonstrated that hydrophobic interactions at the active site pocket are a key feature. This structure, together with molecular modeling, provides insight into the selectivity of the PDE inhibitors and a template for the discovery of new PDE7 or PDE7/PDE4 dual inhibitors.
\end{abstract}

\section{Keywords}

drug design; inflammation; PDE7; thioxoquinazolines

(C) 2009 Wiley-VCH Verlag GmbH \& Co. KGaA, Weinheim

Fax: (+34) 91 5644853, cgil@iqm.csic.es.

Supporting information for this article is available on the WWW under http://dx.doi.org/10.1002/cmdc.200900043. 


\section{Introduction}

Phosphodiesterases (PDEs) are a large family of metallophos-phohydrolase enzymes that ubiquitously metabolize the second messengers adenosine and guanosine $3^{\prime}, 5^{\prime}$-cyclic monophosphates (cAMP and cGMP) to their respective inactive 5'-monophosphates.[1] cAMP and cGMP are synthesized by adenylyl and guanylyl cyclases respectively, and mediate the action of hormones, neurotransmitters, and other cellular effectors in many physiologic processes. As elevation of intracellular cAMP level impacts immunosuppressive and antiinflammatory properties, [2,3] selective inhibitors of cAMP-specific PDEs have been widely studied as therapeutics for the treatment of human diseases, [4] predominantly immune disorders such as multiple sclerosis[5] and inflammatory processes,[6] and also disorders of the central nervous system (CNS) such as depression, psychosis, and Alzheimer's disease.[7]

PDE families 3B, 4A, 4B, 4D, and 7A1 are predominant in immune cells. [8-10] To date, most of the research has been centered on PDE4 inhibitors because PDE4 represents the major isoenzyme in most T-cell preparations and its selective inhibitors are able to decrease inflammatory cytokine production.[10,11] PDE4 inhibitors have been widely studied as antiinflammatory agents for the treatment of asthma, COPD (chronic obstructive pulmonary disease), rheumatoid arthritis, and multiple sclerosis.[12,13] However, a major drawback of these compounds is the significant side effects such as emesis. To overcome these adverse effects, several strategies to dissociate the beneficial and detrimental effects of PDE4 inhibitors have led to some degree of success and the second generation of PDE4 inhibitors have shown better pharmacokinetic profiles.[14]

An alternative approach is to target other cAMP-specific PDE families that are expressed in pro-inflammatory and immune cells. Initial evidence indicated that PDE7 had an important role in the activation of T-cells.[15,16] However, results based on the use of PDE7A knockout mice $\left(P D E 7 A^{-1-}\right)$ failed to confirm the role of PDE7A in T-cell proliferation and suggested that this phosphodiesterase could have some other role in the regulation of humoral immune responses.[17] Thus, selective PDE7A inhibitors would be essential to elucidate the true potential of PDE7A as a pharmacological target in the context of the immune response.[18] Benzo- and benzothienothiadiazine derivatives, developed in our laboratory, constituted the first heterocyclic family of compounds with PDE7 inhibitory properties.[19,20] Since then, spiroquinazolinones, sulfonamide, thiadiazole, purine, and pyrimidine nucleotide analogues have been described as PDE7 inhibitors.[21-23]

The advent of selective PDE7 inhibitors has allowed the assessment of the functional roles that PDE7 plays in cells and tissues. Although inhibition of PDE7A does not attenuate the proliferation of T-cells per se, it significantly augments the anti-mitogenic and cAMP-elevating activities of PDE4 inhibitors.[24] Therefore, PDE7 or PDE7/PDE4 dual inhibitors would represent a novel class of drugs that could regulate pro-inflammatory and immune T-cell function and be especially useful in treating a wide variety of immune and inflammatory disorders.[25-27] Such drugs may also have less undesirable side effects, such as nausea and vomiting.[28]

The latest scientific findings concerning PDE7 and PDE4 inhibition suggest that selective small-molecule inhibitors of both enzymes could provide a novel approach to treat a variety of immunological diseases. In this context, ligand-based virtual screening studies allowed us to identify thiadiazine and quinazoline derivatives as a new class of PDE7 inhibitors.[29] Our preliminary study revealed that the novel thioxoquinazoline compounds $\mathbf{2}-\mathbf{5}$ were equally potent to the target structure $\mathbf{1}$ (Table 1). On the basis of our previous results, this study is undertaken to explore new modifications on the quinazoline scaffold to better understand their therapeutic relevance. Reported herein is the chemical synthesis of the proposed molecules 
and their inhibition on PDEs. The crystal structure of PDE7 in complex with a potent inhibitor is determined by X-ray crystallography and the insight into the design of PDE7 inhibitors is further illustrated by molecular modeling studies. Cell-based studies were performed to investigate the effects on intracellular cAMP levels and the anti-inflammatory properties of the new compounds.

\section{Results and Discussion}

\section{Chemistry}

The new compounds presented in this study retain the basic skeleton of thioxoquinazoline and an aryl substituent linked to nitrogen 3 , whereas methyl or bromine is introduced in the benzene fused ring. Methylation of the thiocarbonyl group and/or thionation of the carbonyl group is performed on the thioxoquinazoline ring or some thieno- and benzothienopyrimidine compounds reported previously.[29]

To prepare the new quinazoline derivatives 6-13, the condensation between the 2-amino-5bromobenzoic acid or 2-amino-3-methylbenzoic acid and the corresponding isothiocyanate was performed in ethanol at $4^{\circ} \mathrm{C}$ (Scheme 1). The bromoquinazolines 6-9 were obtained according to this procedure in high purity by simple filtration of the crude product. However, a purification step was necessary to obtain methylquinazolines 10-13 after the condensation step.

To obtain the $S$-methyl derivatives 14-25, compounds 2-13 were methylated in DMF at room temperature using methyl iodide and potassium carbonate (Scheme 2).[30] The thionation of the carbonyl group at position 4 of derivatives 2-25 was tried with Lawesson's reagent under reflux in toluene (Scheme 2), but only derivatives 26-32 were obtained.[31,32] Following similar procedures, it was possible to obtain modified thieno- and benzothienopyrimidine (Schemes 3 and 4). Thus, the most active thieno- and benzothienopyrimidine derivatives previously reported $\mathbf{3 3}, \mathbf{3 4}$, and $\mathbf{3 8}$ [29] were methylated, producing $S$-methyl derivatives $\mathbf{3 5}$, 36, and $\mathbf{3 9}$ respectively. Compounds $\mathbf{3 5}$ and $\mathbf{3 9}$ were further thionated at position 4 yielding the corresponding thiocarbonyl derivatives 37 and $\mathbf{4 0}$ (Schemes 3 and 4, respectively). It should be mentioned that compound $\mathbf{3 7}$ proved to be unstable and decomposed after its structural elucidation.

The structures of all new compounds were determined by their analytical and spectroscopic data $\left({ }^{1} \mathrm{H}\right.$ and ${ }^{13} \mathrm{C}$ NMR $)$, which are described in the Experimental Section or in the Supporting Information. Unequivocal assignment of all chemical shifts $\left({ }^{1} \mathrm{H}\right.$ and $\left.{ }^{13} \mathrm{C} N M R\right)$ was performed using two-dimensional experiments such as HSQC for one-bond correlation. The site of substitution was confirmed by the HMBC for long distance proton-carbon correlation.

\section{In vitro evaluation of PDE inhibition}

The new derivatives were tested for their inhibitory potencies against the catalytic domain of PDE7A1 and full-length PDE4D2 as described in the Experimental Section (Table 2). Among the new heterocyclic compounds, some of them $(\mathbf{1 3 - 1 5}, \mathbf{1 9 - 2 1}, \mathbf{2 3}, \mathbf{2 5}, \mathbf{2 6}, \mathbf{2 9}$, and 36-39) are more potent than the previous quinazoline derivatives 2-5.[29] In addition, compounds $\mathbf{1 5}$, 19, 23, 25, 29, and 39, also inhibit PDE4, and therefore can be considered as potential PDE7/ PDE4 dual inhibitors for the treatment of T-cell disorders. In addition, the $S$-methyl derivatives have better activity than the previously described compounds ( $\mathrm{IC}_{50}$ values of $0.51 \mu_{\mathrm{M}}$ for $\mathbf{1 5}$ and $0.13 \mu_{\mathrm{M}}$ for $\mathbf{2 3}$ ). Strikingly, among the members of this $S$-methyl family, compounds $\mathbf{1 8}$ and 22, which bear a phenyl group at position 3 , are less active than $\mathbf{1 5}, \mathbf{1 9}, \mathbf{2 3}$, and $\mathbf{2 5}$, which are mono- or di-substituted at the ortho position of the benzene ring. The compounds with the benzene fused ring replaced by a thieno or benzothieno moiety show similar activity. 


\section{Cell viability determined by PI exclusion}

To evaluate potential in vivo use of these compounds, cell-based studies were performed. To this end, we determined the effect of PDE inhibitors 2, 5, 13, 15, 19-23, 25-27, 29, 30, 32, $\mathbf{3 6}, \mathbf{3 9}$, and $\mathbf{4 0}$ on T-cell viability by studying propidium iodide (PI) exclusion in the murine T-cell line D10.G4.1 and subsequent flow cytometry analysis. We used this cell line because PDE7 is abundantly expressed in murine T-cells[33] and the percentage of identity between human and murine PDE7 is 90-96\%.[34]

Cells were cultured in the presence of different concentrations of each PDE inhibitor for $48 \mathrm{~h}$ before flow cytometry analysis. Cell viability was quantified as the percentage of PIimpermeable cells and known selective inhibitors BRL50481 (PDE7) and Rolipram (PDE4) were used as references. Figure 1 shows dose-dependent effects for almost all the inhibitors, which are compatible with their inhibition of PDE7A in vitro.

\section{Intracellular cAMP levels}

The next step was to check if our compounds were able to regulate intracellular cAMP levels in the T-cell clone D10.G4.1. PDE4 inhibitor Rolipram is more effective than PDE7 inhibitor BRL50481 in the induction of intracellular levels of cAMP (Figure 2). Compound 26 was able to increase cAMP to the same level as those induced by BRL50481. Simultaneous addition of Rolipram with BRL50481 or inhibitor $\mathbf{2 6}$ had a synergistic effect on intracellular cAMP levels. This result is consistent with the previous report for BRL50481.[24] In fact, the new inhibitor 26 showed an almost identical behavior in increasing the intracellular cAMP level.

\section{Anti-inflammatory effects}

To verify our working hypothesis that the inflammatory response could be modulated by cAMP levels, we next tested the potential anti-inflammatory effects of our new PDE7 inhibitors 13, 15, and 26 in a cell-based model. To this end, lipopolysaccharide (LPS) was used to induce an inflammatory response in the murine macrophage cell line. The standard reference BRL50481 showed an anti-inflammatory effect as measured by a significant decrease in nitrite production. The new PDE7 inhibitors showed the same biological behavior and significantly decreased nitrite production (Figure 3).

Notably, Rolipram decreased nitrite production to the same extent as BRL50481, whereas its effect in increasing cAMP levels was much more marked. We again found a synergy between the PDE7 inhibitors and Rolipram, and a dramatic decrease in nitrite levels was detected when these PDE7 inhibiting compounds or BRL50481 were used in conjunction with Rolipram (Figure 3). These results confirm that compounds 15, 26, and 13 are good candidates for further analysis in animal models of inflammatory diseases.

\section{Prediction of BBB permeation}

ADME (absorption, distribution, metabolism, and excretion) properties such as the ability to cross the blood-brain barrier (BBB) are important properties to indicate the usefulness of lead compounds. Herein, we determined in silico the ability of some of the newly synthesized compounds to cross the BBB using our CODES-based model.[35] According to the model, our most promising candidates were able to cross the BBB and could therefore be used as potential new drugs for the treatment of neurological disorders (table S1 in the Supporting Information).

\section{Binding mode of PDE7 inhibitors: crystal structure of PDE7A1-compound 15}

The crystallographic data on the catalytic domain of PDE7A1 in complex with the nonselective inhibitor 3-isobutyl-1-methylxanthine (IBMX; PDB code 1ZKL)[36] prompted us to use the 
same methodology to reveal the structural basis for the biological function of the potent compound $15\left(\mathrm{IC}_{50}=0.51 \mu_{\mathrm{M}}\right)$. The structure of PDE7A1 (residues 130-482) in complex with $\mathbf{1 5}$ has the topological folding of PDE7A1-IBMX.[36] The structural superposition of the PDE7A1-15 and PDE7A1-IBMX complexes yielded a root-mean-square deviation (RMSD) of $0.18 \AA$, indicating that the two inhibitor-bound structures are similar. Residues 130-138 and 457-482 were not traceable in the structure because of a lack of electron density. The structure contains $16 \alpha$ helices (Figure 4) and has the same folding topology as those of other PDEs. [37]

The two essential elements for binding of all PDE inhibitors are stacking against a conserved phenylalanine and the hydrogen bond with an invariant glutamine.[37] In our case, compound 15 binds to the active site of PDE7A1 and forms hydrophobic interactions with residues Ile323, Ile363, Val380, Phe384, Leu401, Phe416, and Leu420 (Figure 4) and an aromatic interaction with the conserved Phe416. However, the hydrogen bond with Gln413 is not present in the Xray crystal structure of the PDE7A1-15 complex.

As hydrophobic interactions are typically nonspecific, we were curious if compound $\mathbf{1 5}$ is also potent in inhibition of other PDE families. The enzymatic assay showed that compound $\mathbf{1 5}$ at a concentration of $200 \mu_{\mathrm{M}}$ did not inhibit cGMP-specific PDE5 and PDE9. However, 15 moderately inhibited PDE2A, PDE3A, and PDE10A with $\mathrm{IC}_{50}$ values of 8.2, 65.0, and 11.3 $\mu_{\mathrm{M}}$, respectively. Thus, 15 showed $16,127,6.9,>392,>392$, and 22-fold selectivity against PDE2A, PDE3A, PDE4D, PDE5A, PDE9A, and PDE10A, with respect to PDE7A (IC $50=0.51$ $\left.\mu_{\mathrm{M}}\right)$.

\section{Theoretical binding studies}

Keeping in mind the hydrophobic nature of the interaction of $\mathbf{1 5}$ in the binding site of PDE7A1, the observed selectivity against PDE enzymes is surprising, especially if we take into account that several residues that define the binding site are distant from the inhibitor (Figure 5 and Table 3). To gain insight into the molecular determinants responsible for such selectivity, compound 15 was docked in the binding site of PDE7A1 using the program rDock. This docking allowed us to reproduce the binding mode that has an RMSD of less than $2 \AA$ from a series of the observed X-ray crystal structures of PDE4 inhibitors (see Supporting Information). In addition to the X-ray crystallographic binding mode (mode B), the docking revealed an alternative pose with a slightly better score (Figure 5; mode A), in which the inhibitor partially overlapped with the region occupied by mode B, but penetrated deeper into the binding pocket. Interestingly, this latter binding mode enables the carbonyl oxygen of $\mathbf{1 5}$ to form a hydrogen bond with the side chain $\mathrm{NH}_{2}$ group of Gln413, while the stacking against Phe416 is retained. Accordingly, this binding mode mimics the basic trends observed for the binding of IBMX to PDE7. Similar results were found in the docking of the thieno derivative $\mathbf{3 6}$ (data not shown).

As docking scoring functions are typically developed to allow a high computational speed in the virtual screening of a large collection of compounds, they involve a number of approximations that limit their accuracy in predicting the most favorable docking poses. Therefore, MM/PBSA (molecular mechanics/ Poisson-Boltzmann surface area), which has been successfully applied to predict the relative affinities of structurally related ligands, [3841] was used to evaluate the relative affinity of the two binding modes of the inhibitor. This technique combines a rigorous treatment of electrostatics, which includes solvent screening effects upon complex formation, as well as nonpolar terms for the van der Waals interactions between inhibitor and receptor, and for the desolvation free energy. For our purposes, this technique appears to be well suited to discriminate between the different poses of the same inhibitor in the binding site of PDE7A1. 
Although the choice of the solute dielectric constant affected the absolute values of the electrostatic components of the binding affinity (Table 4), it has much less impact on the differences between the two binding modes. The nonpolar contribution to the solvation free energy is very similar in the two binding modes. In contrast, the van der Waals term shows a $6.4 \mathrm{kcal} \mathrm{mol}^{-1}$ energy difference, favoring the alternative binding mode A over the X-ray-like binding mode. The preference of this binding mode is counter balanced by the difference in the internal energy $\left(2.9 \mathrm{kcal} \mathrm{mol}^{-1}\right)$, which reflects the conformational penalty due to rearrangements of the side chains of residues. Nevertheless, this opposing term is not sufficient to compensate for the larger energy in the van der Waals interaction between the receptor and inhibitor in binding mode $\mathrm{A}$.

A feature of particular relevance in the A binding mode is that the difluoro-substituted benzene ring points toward Ser373, which is one of the often divergent residues in the binding site of phosphodiesterases (see Figure 5 and Table 3). As Ser373 is replaced by Tyr in PDE4, it is reasonable to expect that the bulkier size of the PDE4 residue can increase the steric hindrance with the difluoro-substituted benzene ring and eventually weaken the hydrogen bond with the glutamine in PDE4. For PDE2 and PDE10, even though Ser373 is replaced by Thr, Pro366 is mutated to Gln and Val respectively, whose side chains might also affect the positioning of the difluorobenzene unit of $\mathbf{1 5}$ in their binding site. More drastic changes are found in PDE3, PDE5, and PDE9. Thus, Ser373 and Pro366 are mutated respectively to His and Val in PDE3, Gln and Ile in PDE5, and Ala and Glu in PDE9. Therefore, altering the shape, size, and electrostatic features of these residues may contribute to the selective binding of compound 15, and Ser373 may be an important residue for the selectivity of PDE inhibitors.

Overall, it can be speculated that the adoption of binding mode A could follow a two-step binding mechanism, where the conversion from mode B could be limited by local structural rearrangements of the side chains of residues that surround Ser373. Future modifications of the inhibitors aim at retaining the interaction with the invariant Gln413, whereas the amino acid divergence across PDEs is valuable for increasing the binding affinity and selectivity of this novel class of PDE7 inhibitors.

\section{Conclusions}

Phosphodiesterase 7 is a high-affinity cAMP-specific PDE, the functional role of which in Tcells has been the subject of some controversy. However, recent findings on tissue distribution support the hypothesis that PDE7 could be a good target for the treatment of airway diseases, T-cell related diseases, or even CNS disorders. Thus, the discovery of PDE7 inhibitors is essential for the treatment of these disorders. The new heterocyclic compounds reported herein are more potent than the previous quinazoline derivatives for the inhibition of PDE7. As a result of their capability to inhibit PDE4, compounds 15, 19, 23, 25, 29, and 39 can be considered as potential PDE7/PDE4 dual inhibitors for the treatment of T-cell disorders. The derivatives 13, 26, and $\mathbf{4 0}$ show moderate in vitro cell toxicity similar to Rolipram or BRL50481. Also thioxoquinazoline derivatives show a synergistic effect with Rolipram in increasing intracellular levels of cAMP.

These compounds have remarkable anti-inflammatory activity, as shown by a significant decrease in nitrite production in the murine macrophage cell line in response to the LPS stimulation. Again, synergy between PDE4 and PDE7 inhibitors is observed. Moreover, the in silico model predicts that the thioxoquinazolines are able to cross the $\mathrm{BBB}$, further emphasizing their potential biological use. 
Last of all, the structure of the PDE7A1-15 complex allows us to better understand the binding site of this new family of PDE7 inhibitors, providing some important clues for the design of new and selective inhibitors.

Overall, structural optimization on the thioxoquinazoline derivatives led to new compounds with a very interesting profile as PDE7 or PDE7/PDE4 dual inhibitors that may be further developed as new drugs for inflammatory and neurological diseases. Our hypothesis is based on the fact that a decrease in cAMP levels promotes inflammation. Therefore, for diseases in which PDEs are overexpressed or are overactive, PDE inhibitors will be useful as therapeutic agents. This fact has been proven with PDE4 inhibitors for smooth-tissue diseases and COPD, and it will be checked in the near future with PDE7 inhibitors for neurological disease, as PDE7 is widely expressed in the brain. Modulation of the inflammation process is without a doubt a well-established neuroprotective strategy.

\section{Experimental Section}

\section{Chemical procedures}

Chemicals were purchased from commercial sources and used without further purification. Melting points were measured by a Reichert-Jung Thermovar apparatus and were not corrected. Flash column chromatography was carried out at medium pressure with silica gel 60 (E. Merck, particle size $0.040-0.063 \mathrm{~mm}, 230-240$ mesh ASTM) and the indicated solvent as eluent. Compounds were detected with UV light $(254 \mathrm{~nm}) .{ }^{1} \mathrm{H}$ NMR spectra were obtained on the Bruker Avance 300 spectrometer working at $300 \mathrm{MHz}$. Typical spectral parameters: spectral width $10 \mathrm{ppm}$, pulse width $9 \mu \mathrm{s}\left(57^{\circ}\right)$, data size $32 \mathrm{~K} .{ }^{13} \mathrm{C}$ NMR experiments were carried out on a Bruker Avance 300 spectrometer operating at $75 \mathrm{MHz}$. The acquisition parameters: spectral width $16 \mathrm{kHz}$, acquisition time $0.99 \mathrm{~s}$, pulse width $9 \mu \mathrm{s}\left(57^{\circ}\right)$, data size $32 \mathrm{~K}$. Chemical shifts are reported in ppm relative to internal $\mathrm{Me}_{4} \mathrm{Si}$, and $J$ values are reported in Hz. IR spectra were recorded on a PerkinElmer Spectrum One spectrometer. EIMS data were collected on an MSD 5973 instrument (Hewlett-Packard), and ESIMS data on an LC/ MSD Series 100 (Hewlett-Packard). Elemental analyses were performed by the analytical department at CENQUIOR (CSIC), and the results obtained were within $\pm 0.4 \%$ of the theoretical values.

\section{General procedure for the synthesis of thioxoquinazoline derivatives (6-13)-} The corresponding isothiocyanate derivative ( 1 equiv) at $0^{\circ} \mathrm{C}$ was added to a solution of the commercially available 2-amino-5-bromobenzoic acid or 2-amino-3-methylbenzoic acid (1 equiv) in $\mathrm{EtOH}$. The reaction mixture was stirred at $4^{\circ} \mathrm{C}$ during the time indicated in each case, and the product was isolated by filtration. Sometimes a purification step was necessary. A representative example (compound $\mathbf{6}$ ) is characterized below; full experimental details for compounds 7-13 are given in the Supporting Information.

6-Bromo-4-oxo-3-phenyl-2-thioxo-1,2,3,4-tetrahydroquinazoline (6)-Reagents: 2-amino-5-bromobenzoic acid $(0.80 \mathrm{~g}, 3.70 \mathrm{mmol})$, phenylisothiocyanate $(0.4 \mathrm{~mL}, 3.70$ $\mathrm{mmol})$, EtOH (37.0 mL). Conditions: 3 days. Yield: $0.49 \mathrm{~g} \mathrm{(40 \% )} \mathrm{as} \mathrm{a} \mathrm{white} \mathrm{solid;} \mathrm{mp:} 326-$ $329^{\circ} \mathrm{C}$ (lit.[42] 322-325 $5^{\circ} \mathrm{C}$ ); ${ }^{1} \mathrm{H}$ NMR (300 MHz, [D 6 ]DMSO): $\delta=13.22$ (br s, $1 \mathrm{H}, \mathrm{NH}$ ), 8.09 (d, $1 \mathrm{H}, J=2.1 \mathrm{~Hz}, \mathrm{H}-5), 8.03$ (dd, 1H, $J=8.7,2.1 \mathrm{~Hz}, \mathrm{H}-7$ ), 7.50-7.37 (m, 4H, Ar-H, H-8), $7.35 \mathrm{ppm}(\mathrm{d}, 2 \mathrm{H}, J=7.3 \mathrm{~Hz}, \mathrm{Ar}-\mathrm{H}) ;{ }^{13} \mathrm{C}$ NMR $\left(75 \mathrm{MHz},\left[\mathrm{D}_{6}\right] \mathrm{DMSO}\right): \delta=176.0(\mathrm{C} 2), 158.7$ (C4), 139.1 (Ar-C), 138.8 (C8a), 138.1 (C7), 129.2 (C5), 128.9 (2 C, Ar-C), 128.8 (2 C, ArC), 128.1 (Ar-C), 118.2 (C8), 118.0 (C4a), 115.7 ppm (C6); IR (KBr): $\tilde{v}=3237,3033,1663$, $1522,1214 \mathrm{~cm}^{-1}$; MS (ESI) $\mathrm{m} / \mathrm{z} 333,335[\mathrm{M}+\mathrm{H}]^{+}, 355,357[\mathrm{M+Na}]^{+}$; Anal. calcd for $\mathrm{C}_{14} \mathrm{H}_{9} \mathrm{BrN}_{2} \mathrm{OS}$ : C 50.46, H 2.72, N 8.41, S 9.62, found: C 50.19, H 2.88, N 8.35, S 9.34. 
General procedure for the synthesis of 2-methylthio-4-oxo-3,4-

dihydroquinazoline derivatives (14-25)-Anhydrous $\mathrm{K}_{2} \mathrm{CO}_{3}$ (1 equiv) was added to a solution of the corresponding 4-oxo-2-thioxo-1,2,3,4-tetrahydroquinazoline derivative (1 equiv) in anhydrous DMF, and the mixture was stirred at RT for $1 \mathrm{~h}$. To this solution, MeI (1.5 equiv) was added, and the reaction mixture was stirred at RT to completion. The solvent was evaporated under reduced pressure. The residue was purified by using flash chromatography, eluting with hexane/EtOAc in the proportions indicated. A representative example (compound 14) is characterized below; full experimental details for compounds 15-25 are given in the Supporting Information.

2-Methylthio-4-oxo-3-phenyl-3,4-dihydroquinazoline (14)—Reagents: 4-oxo-3phenyl-2-thioxo-1,2,3,4-tetrahydroquinazoline (2)[29] (0.20 g, $0.78 \mathrm{mmol}), \mathrm{K}_{2} \mathrm{CO}_{3}(0.10 \mathrm{~g}$, $0.78 \mathrm{mmol}), \mathrm{DMF}(16.9 \mathrm{~mL}), \mathrm{MeI}(72.8 \mu \mathrm{L}, 1.17 \mathrm{mmol})$. Conditions: $7 \mathrm{~h}$. Purification: hexane/ EtOAc (5:1) as eluent. Yield: $0.15 \mathrm{~g}(76 \%)$ as a white solid; mp: $121-123^{\circ} \mathrm{C}$ (lit. [43] 124-126 C); purity: $97 \%$ (by HPLC); ${ }^{1} \mathrm{H}$ NMR $\left(300 \mathrm{MHz}, \mathrm{CDCl}_{3}: \delta=8.15\right.$ (dd, $1 \mathrm{H}, J=7.9,1.3 \mathrm{~Hz}$, H-5), 7.63 (ddd, $1 \mathrm{H}, J=8.0,7.8,1.3 \mathrm{~Hz}, \mathrm{H}-7), 7.54$ (d, $1 \mathrm{H}, J=7.8 \mathrm{~Hz}, \mathrm{H}-8), 7.49-7.42$ (m, $3 \mathrm{H}, \mathrm{Ar}-\mathrm{H}), 7.29$ (ddd, 1H, J = 8.0, 7.9, 1.0 Hz, H-6), 7.24-7.20 (m, 2H, Ar-H), 2.43 (s, 3H, $\mathrm{Me}) ;{ }^{13} \mathrm{C} \mathrm{NMR}\left(75 \mathrm{MHz}, \mathrm{CDCl}_{3}\right): \delta=161.7(\mathrm{C} 4), 157.8(\mathrm{C} 2), 147.7$ (C8a), 135.9 (Ar-C), 134.5 (C7), 129.8 (Ar-C), 129.5 (2 C, Ar-C), 129.0 (2 C, Ar-C), 127.1 (C5), 126.1 (C8), 125.6 (C6), 119.7 (C4a), 15.4 (Me); IR (KBr): $\tilde{v}=3070,2929,1700,1595,1264 \mathrm{~cm}^{-1}$; MS (ESI) $\mathrm{m} / z 269[M+\mathrm{H}]^{+}, 291[M+\mathrm{Na}]^{+}, 559[2 M+\mathrm{Na}]^{+}, 560[2 M+\mathrm{Na}+\mathrm{H}]^{+}$; Anal. calcd for $\mathrm{C}_{15} \mathrm{H}_{12} \mathrm{~N}_{2} \mathrm{OS}$ : C 67.14, H 4.51, N 10.44, S 11.95, found: C 66.97, H 4.38, N 10.31, S 11.79.

\section{General procedure for the synthesis of 2,4-dithioxo-1,2,3,4- tetrahydroquinazoline derivatives (26-28)-2,4-bis(4-methoxyphenyl)-1,3,2,4-} dithiadiphosphetane-2,4-disulfide (Lawesson's reagent; 1.5 equiv) was added to a solution of the corresponding 4-oxo-2-thioxo-1,2,3,4-tetrahydroquinazoline derivative (1 equiv) in toluene, and the mixture was heated under reflux to completion. After cooling to RT, the solvent was evaporated under reduced pressure. The residue was purified by using flash chromatography, eluting with hexane/EtOAc in the proportions indicated. A representative example (compound 26) is characterized below; full experimental details for compounds $\mathbf{2 7}$ and $\mathbf{2 8}$ are given in the Supporting Information.

3-Phenyl-2,4-dithioxo-1,2,3,4-tetrahydroquinazoline (26)—Reagents: 2[29] (75.0 $\mathrm{mg}, 0.29 \mathrm{mmol})$, Lawesson's reagent $(0.17 \mathrm{~g}, 0.44 \mathrm{mmol})$, toluene $(6.4 \mathrm{~mL})$. Conditions: 24 h. Purification: hexane/EtOAc (9:1) as eluent. Yield: $50.3 \mathrm{mg}$ (63\%) as an orange solid; mp: 253-256 ${ }^{\circ} \mathrm{C}$ (lit.[44] $252-254{ }^{\circ} \mathrm{C}$ ); purity: $98 \%$ (by HPLC); ${ }^{1} \mathrm{H}$ NMR $\left(300 \mathrm{MHz},\left[\mathrm{D}_{6}\right.\right.$ ]DMSO): $\delta=13.48(\mathrm{br} \mathrm{s}, 1 \mathrm{H}, \mathrm{NH}), 8.32(\mathrm{dd}, 1 \mathrm{H}, J=8.2,1.0 \mathrm{~Hz}, \mathrm{H}-5), 7.78$ (ddd, $1 \mathrm{H}, J=8.3,7.0,1.0$ Hz, H-7), 7.50-7.42 (m, 3H, Ar-H, H-6), 7.39-7.32 (m, 2H, Ar-H, H-8), 7.21 ppm (dd, 2H, $J=8.3,1.1 \mathrm{~Hz}, \mathrm{Ar}-\mathrm{H}) ;{ }^{13} \mathrm{C}$ NMR $\left(75 \mathrm{MHz},\left[\mathrm{D}_{6}\right] \mathrm{DMSO}\right): \delta=189.8(\mathrm{C} 4), 172.8(\mathrm{C} 2), 144.2$ (Ar-C), 135.8 (C7), 135.2 (C8a), 131.7 (C5), 129.2 (2C, Ar-C), 128.5 (2C, Ar-C), 127.9 (ArC), 125.2 (C8), 123.7 (C4a), 115.9 ppm (C6); IR (KBr): $\tilde{v}=3159,3101,3007$, 2953, 1537, $1478,1209 \mathrm{~cm}^{-1}$; MS (ESI) $\mathrm{m} / z 271[\mathrm{M+H}]^{+}, 293[\mathrm{M+Na}]^{+}$; MS (EI) $\mathrm{m} / z, 270[M]^{+}(60)$; Anal. calcd for $\mathrm{C}_{14} \mathrm{H}_{10} \mathrm{~N}_{2} \mathrm{~S}_{2}$ : C 62.19, H 3.73, N 10.36, S 23.72, found: C 62.32, H 3.82, N 10.01, S 23.60 .

\section{General procedure for the synthesis of 2-methylthio-4-thioxo-3,4-}

dihydroquinazoline derivatives (29-32)-2,4-bis(4-methoxyphenyl)-1,3,2,4-

dithiadiphosphetane-2,4-disulfide (Lawesson's reagent; 1.5 equiv) was added to a solution of the corresponding 2-methylthio-4-oxo-3,4-dihydroquinazoline derivative (1 equiv) in toluene, and the mixture was heated under reflux to completion. After cooling to RT, the solvent was evaporated under reduced pressure. The residue was purified by using flash chromatography, 
eluting with hexane/EtOAc in the proportions indicated. A representative example (compound 29) is characterized below; full experimental details for compounds 30-32 are given in the Supporting Information.

2-Methylthio-3-phenyl-4-thioxo-3,4-dihydroquinazoline (29)—Reagents: 14 (75.0 $\mathrm{mg}, 0.27 \mathrm{mmol})$, Lawesson's reagent $(0.16 \mathrm{~g}, 0.41 \mathrm{mmol})$, toluene $(6.1 \mathrm{~mL})$. Conditions: 24 h. Purification: hexane/EtOAc (6:1) as eluent. Yield: $73.9 \mathrm{mg}(93 \%)$ as a yellow solid, $\mathrm{mp}$ : 180-182 ${ }^{\circ} \mathrm{C}$; purity: $98 \%$ (by HPLC); ${ }^{1} \mathrm{H} \mathrm{NMR}\left(300 \mathrm{MHz}, \mathrm{CDCl}_{3}\right): \delta=8.68$ (ddd, $1 \mathrm{H}, J=$ 8.2, 1.3, 0.3 Hz, H-5), 7.70 (ddd, $1 \mathrm{H}, J=8.2,6.9,1.3 \mathrm{~Hz}, \mathrm{H}-7$ ), 7.59 (dd, $1 \mathrm{H}, J=8.2,0.9 \mathrm{~Hz}$, H-8), 7.56-7.51 (m, 3H, Ar-H), 7.37 (ddd, $1 \mathrm{H}, J=8.2,6.9,0.9 \mathrm{~Hz}, \mathrm{H}-6), 7.26-7.22$ (m, 2H, Ar-H), 2.49 ppm (s, 3H, Me); $\left.{ }^{13} \mathrm{C} \mathrm{NMR} \mathrm{(75} \mathrm{MHz,} \mathrm{CDCl}_{3}\right): \delta=189.9(\mathrm{C} 4), 157.4(\mathrm{C} 2), 142.8$ (C8a), 140.4 (Ar-C), 134.8 (C7), 131.1 (C5), 129.9 (Ar-C), 129.8 (2C, Ar-C), 128.8 (2C, ArC), 127.5 (C4a), 126.9 (C6), 126.8 (C8), $16.0 \mathrm{ppm}(\mathrm{Me})$; IR (KBr): $v=3060,2925,1570,1533$, $1262,1203 \mathrm{~cm}^{-1}$; MS (ESI) $\mathrm{m} / z 285[M+\mathrm{H}]^{+}, 307[\mathrm{M+Na}]^{+}, 591[2 M+\mathrm{Na}]^{+}$; Anal. calcd for $\mathrm{C}_{15} \mathrm{H}_{12} \mathrm{~N}_{2} \mathrm{~S}_{2}$ : C 63.35, H 4.25, N 9.85, S 22.55, found: C 63.58, H 4.76, N 9.83, S 22.30.

\section{General procedure for the synthesis of 2-methylthio-4-oxo-3,4-dihydrothieno} [3,2- $d$ ]pyrimidine derivatives $(35,36)$-Anhydrous $\mathrm{K}_{2} \mathrm{CO}_{3}$ (1 equiv) was added to a solution of the corresponding 4-oxo-2-thioxo-1,2,3,4-tetrahydrothieno[3,2- $d]$ pyrimidine derivative (1 equiv) in anhydrous DMF, and the mixture was stirred at RT for $1 \mathrm{~h}$. To this solution, MeI (1.5 equiv) was added, and the reaction mixture was stirred at RT for $6 \mathrm{~h}$. The solvent was evaporated under reduced pressure. The residue was purified by using flash chromatography, eluting with hexane/EtOAc (4:1).

2-Methylthio-4-oxo-3-phenyl-3,4-dihydrothieno[3,2-d]pyrimidine (35)—Reagents: 4-oxo-3-phenyl-2-thioxo-1,2,3,4-tetrahydrothieno-[3,2-d]pyrimidine (33)[29] (0.15 g, 0.57 $\mathrm{mmol}), \mathrm{K}_{2} \mathrm{CO}_{3}(79.7 \mathrm{mg}, 0.57 \mathrm{mmol}), \mathrm{DMF}(12.5 \mathrm{~mL})$, MeI (53.8 $\left.\mu \mathrm{L}, 0.86 \mathrm{mmol}\right)$. Yield: 0.12 $\mathrm{g}(77 \%)$ as a white solid; mp: $188-190{ }^{\circ} \mathrm{C}$; purity: > 99\% (by HPLC); ${ }^{1} \mathrm{H}$ NMR $(300 \mathrm{MHz}$, $\left.\mathrm{CDCl}_{3}\right): \delta=7.67(\mathrm{~d}, 1 \mathrm{H}, J=5.2 \mathrm{~Hz}, \mathrm{H}-6), 7.50-7.44(\mathrm{~m}, 3 \mathrm{H}, \mathrm{Ar}-\mathrm{H}), 7.27-7.22(\mathrm{~m}, 2 \mathrm{H}, \mathrm{Ar}-$ $\mathrm{H}), 7.19(\mathrm{~d}, 1 \mathrm{H}, J=5.2 \mathrm{~Hz}, \mathrm{H}-7), 2.42 \mathrm{ppm}(\mathrm{s}, 3 \mathrm{H}, \mathrm{Me}) ;{ }^{13} \mathrm{C} \mathrm{NMR}\left(75 \mathrm{MHz}, \mathrm{CDCl}_{3}\right): \delta=$ 160.2 (C2), 158.0 (C4), 156.5 (C7a), 135.6 (Ar-C), 134.4 (C6), 129.9 (Ar-C) $), 129.6$ (2C, ArC), 129.0 (2C, Ar-C), 124.4 (C7), 119.6 (C4a), 15.6 ppm (Me); IR (KBr): v = 3100, 3085, 2993, 1676, 1496, $1238 \mathrm{~cm}^{-1}$; MS (ESI) $\mathrm{m} / z 275[\mathrm{M}+\mathrm{H}]^{+}, 297[\mathrm{M}+\mathrm{Na}]^{+}, 589[2 \mathrm{M}+\mathrm{Na}$ $\left.+\mathrm{NH}_{4}\right]^{+}$; Anal. calcd for $\mathrm{C}_{13} \mathrm{H}_{10} \mathrm{~N}_{2} \mathrm{OS}_{2}: \mathrm{C} 56.91, \mathrm{H} 3.67, \mathrm{~N} 10.21, \mathrm{~S} 23.37$, found: C 56.67, H $3.89, \mathrm{~N} 10.06, \mathrm{~S} 23.11$.

\section{3-(2,6-Difluorophenyl)-2-methylthio-4-oxo-3,4-dihydrothieno-[3,2-d]pyrimidine}

(36)-Reagents: 3-(2,6-difluorophenyl)-4-oxo-2-thioxo-1,2,3,4-tetrahydrothieno[3,2-d] pyrimidine (34)[29] (60.0 mg, $0.20 \mathrm{mmol}), \mathrm{K}_{2} \mathrm{CO}_{3}(28.0 \mathrm{mg}, 0.20 \mathrm{mmol}), \mathrm{DMF}(4.4 \mathrm{~mL}), \mathrm{MeI}$ $(18.9 \mu \mathrm{L}, 0.30 \mathrm{mmol})$. Yield: $26.7 \mathrm{mg}(43 \%)$ as a white solid; $\mathrm{mp}: 158-160^{\circ} \mathrm{C}$; purity: $96 \%$ (by HPLC); ${ }^{1} \mathrm{H}$ NMR $\left(300 \mathrm{MHz}, \mathrm{CDCl}_{3}\right): \delta=7.81(\mathrm{~d}, 1 \mathrm{H}, J=5.2 \mathrm{~Hz}, \mathrm{H}-6), 7.61-7.48(\mathrm{~m}$, $1 \mathrm{H}, \mathrm{Ar}-\mathrm{H}), 7.29(\mathrm{~d}, 1 \mathrm{H}, J=5.2 \mathrm{~Hz}, \mathrm{H}-7), 7.15-7.09(\mathrm{~m}, 2 \mathrm{H}, \mathrm{Ar}-\mathrm{H}), 2.56 \mathrm{ppm}(\mathrm{s}, 3 \mathrm{H}$, $\mathrm{Me}) ;{ }^{13} \mathrm{C}$ NMR (75 MHz, $\left.\mathrm{CDCl}_{3}\right): \delta=159.7$ (C2), 159.0 (dd, 2C, $\left.J=253.8,3.5 \mathrm{~Hz}, \mathrm{Ar}-\mathrm{C}\right)$, 156.7 (C7a), 156.7 (C4), 134.9 (C6), 132.2 (t, 1C, J = 9.8 Hz, Ar-C), 124.6 (C7), 119.0 (C4a), 112.8 (t, $1 \mathrm{C}, J=16.8 \mathrm{~Hz}, \mathrm{Ar}-\mathrm{C}$ ), 112.4 (dd, 2C, $J=19.7,3.3 \mathrm{~Hz}, \mathrm{Ar}-\mathrm{C}), 15.2 \mathrm{ppm}(\mathrm{Me}) ; \mathrm{IR}$ (KBr): $v=3072,2923,2853,1684,1503,1237,1009 \mathrm{~cm}^{-1}$; MS (EI) m/z $310[M]^{+}$(83); Anal. calcd for $\mathrm{C}_{13} \mathrm{H}_{8} \mathrm{~F}_{2} \mathrm{~N}_{2} \mathrm{OS}_{2}$ : C 50.31, H 2.60, N 9.03, S 20.66, found: C 50.12, H 2.90, N 8.94, S 20.37 .

2-Methylthio-3-phenyl-4-thioxo-3,4-dihydrothieno[3,2-d]pyrimidine (37)-2,4-bis (4-methoxyphenyl)-1,3,2,4-dithiadiphosphetane-2,4-disulfide (Lawesson's reagent; $0.15 \mathrm{~g}$, $0.38 \mathrm{mmol}$ ) was added to a solution of $\mathbf{3 5}(70.0 \mathrm{mg}, 0.25 \mathrm{mmol})$ in toluene $(5.5 \mathrm{~mL})$, and the 
mixture was heated under reflux for $24 \mathrm{~h}$. After cooling to RT, the solvent was evaporated under reduced pressure. The residue was purified by using flash chromatography, eluting with hexane/EtOAc $(5: 1)$ to yield $63.3 \mathrm{mg}(86 \%)$ of a yellow solid; ${ }^{1} \mathrm{H}$ NMR $\left(300 \mathrm{MHz}, \mathrm{CDCl}_{3}\right)$ : $\delta=7.82(\mathrm{~d}, 1 \mathrm{H}, J=5.4 \mathrm{~Hz}, \mathrm{H}-6), 7.60-7.53$ (m, 3H, Ar-H), 7.29-7.24 (m, 3H, Ar-H, H-7), $2.47 \mathrm{ppm}(\mathrm{s}, 3 \mathrm{H}, \mathrm{Me}) ;{ }^{13} \mathrm{C} \mathrm{NMR}\left(75 \mathrm{MHz}, \mathrm{CDCl}_{3}\right): \delta=180.8$ (C4), 160.5 (C2), 149.8 (C7a), 139.2 (Ar-C), 138.2 (C6), 134.9 (C4a), 130.2 (Ar-C), 129.8 (2C, Ar-C), 128.8 (2C, Ar-C), 124.6 (C7), 16.3 ppm (Me); MS (ESI) $m / z, 291[M+\mathrm{H}]^{+}, 332\left[M+\mathrm{Na}+\mathrm{NH}_{4}+\mathrm{H}\right]^{+}$.

\section{3-(2,6-Difluorophenyl)-2-methylthio-4-oxo-3,4-dihydrobenzo-[4,5]thieno[3,2-d]} pyrimidine (39)-Anhydrous $\mathrm{K}_{2} \mathrm{CO}_{3}(59.9 \mathrm{mg}, 0.43 \mathrm{mmol})$ was added to a solution of 3(2,6-difluorophenyl)-4-oxo-2-thioxo-1,2,3,4-tetrahydrobenzo[4,5]thieno[3,2-d]pyrimidine (38)[29] (0.15 g, $0.43 \mathrm{mmol})$ in anhydrous DMF (9.4 mL), and the mixture was stirred at RT for $1 \mathrm{~h}$. To this solution, MeI $(40.5 \mu \mathrm{L}, 0.65 \mathrm{mmol})$ was added, and the reaction mixture was stirred at RT for $4 \mathrm{~h}$. The solvent was evaporated under reduced pressure. The residue was purified by using flash chromatography, eluting with hexane/EtOAc (5:1) to yield $0.14 \mathrm{~g}(92 \%)$ of a white solid; mp: $183-185^{\circ} \mathrm{C} ;{ }^{1} \mathrm{H} \mathrm{NMR}\left(300 \mathrm{MHz}, \mathrm{CDCl}_{3}\right): \delta=8.32(\mathrm{~d}, 1 \mathrm{H}, J=7.7 \mathrm{~Hz}$, H-9), 7.91 (d, 1H, J = 7.8 Hz, H-6), 7.63-7.50 (m, 3H, H-7, Ar-H, H-8), 7.16-7.11 (m, 2H, $\mathrm{Ar}-\mathrm{H}), 2.68 \mathrm{ppm}(\mathrm{s}, 3 \mathrm{H}, \mathrm{Me}) ;{ }^{13} \mathrm{C} \mathrm{NMR}\left(75 \mathrm{MHz}, \mathrm{CDCl}_{3}\right): \delta=160.4(\mathrm{C} 2), 158.8(\mathrm{dd}, 2 \mathrm{C}, J$ = 254.0, 3.5 Hz, Ar-C), 157.2 (C4), 152.2 (C9b), 141.8 (C5a), 134.0 (C9a), 132.3 (t, 1C, J = 9,7 Hz, Ar-C), 129.0 (C7), 125.0 (C8), 123.7 (C9), 123.3 (C6), 118.5 (C4a), 112.8 (t, 1C, $J=$ $16.8 \mathrm{~Hz}, \mathrm{Ar}-\mathrm{C}), 112.4$ (dd, 2C, $J=19.7,3.4 \mathrm{~Hz}, \mathrm{Ar}-\mathrm{C}), 15.3 \mathrm{ppm}(\mathrm{Me})$; IR (KBr): v = 3066, 2925, 1697, 1530, 1497, 1478, 1243, $1013 \mathrm{~cm}^{-1}$; MS (ESI) $m / z 361[M+\mathrm{H}]^{+}, 383[M+\mathrm{Na}]^{+}$, 743 [2M+Na $]^{+}$; Anal. calcd for $\left(\mathrm{C}_{13} \mathrm{H}_{8} \mathrm{~F}_{2} \mathrm{~N}_{2} \mathrm{OS}_{2}\right) \mathrm{C} 50.31, \mathrm{H} 2.60, \mathrm{~N} 9.03, \mathrm{~S}$ 20.66; found: C 50.12, H 2.90, N 8.94, S 20.37; Anal. calcd for $\mathrm{C}_{17} \mathrm{H}_{10} \mathrm{~F}_{2} \mathrm{~N}_{2} \mathrm{OS}_{2}$ : C 56.65, H 2.80, N 7.77, S 17.79, found: C 56.75, H 3.02, N 7.46, S 17.69.

3-(2,6-Difluorophenyl)-2-methylthio-4-thioxo-3,4-dihydrobenzo-[4,5]thieno[3,2d]pyrimidine (40)-2,4-bis(4-methoxyphenyl)-1,3,2,4-dithiadiphosphetane-2,4-disulfide (Lawesson's reagent; $0.12 \mathrm{~g}, 0.31 \mathrm{mmol}$ ) was added to a solution of $\mathbf{3 9}(75.0 \mathrm{mg}, 0.20 \mathrm{mmol}$ ) in toluene $(4.5 \mathrm{~mL})$, and the mixture was heated under reflux for $20 \mathrm{~h}$. After cooling to RT, the solvent was evaporated under reduced pressure. The residue was purified by using flash chromatography, eluting with hexane/EtOAc $(8: 1)$ to yield $23.7 \mathrm{mg}(30 \%)$ of a yellow solid; mp: $250-252^{\circ} \mathrm{C} ;{ }^{1} \mathrm{H}$ NMR $\left(300 \mathrm{MHz}, \mathrm{CDCl}_{3}\right): \delta=8.32(\mathrm{dd}, 1 \mathrm{H}, J=7.8,0.5 \mathrm{~Hz}, \mathrm{H}-9), 7.88$ (d, 1H, $J=8.0 \mathrm{~Hz}, \mathrm{H}-6), 7.64-7.49$ (m, 3H, H-7, Ar-H, H-8), 7.19-7.13 (m, 2H, Ar-H), 2.69 ppm (s, 3H, Me); ${ }^{13} \mathrm{C}$ NMR (75 MHz, $\left.\mathrm{CDCl}_{3}\right): \delta=180.2(\mathrm{C} 4), 161.0(\mathrm{C} 2), 158.1$ (dd, 2C, $J=$ 254.4, 3.8 Hz, Ar-C), 145.7 (C9b), 143.5 (C5a), 134.1 (C9a), 132.6 (t, 1C, J = 9.7 Hz, Ar-C), 129.7 (C7), 125.3 (C8), 124.6 (C9), 123.1 (C6), 116.1 (C4a), 112.8 (Ar-C), 112.6 (dd, 2C, $J=$ 19.2, 3.5 Hz, Ar-C), 15.9 ppm (Me); IR (KBr): $v=3065,2922,1539,1473,1247,1012$ $\mathrm{cm}^{-1}$; MS (ESI) $\mathrm{m} / \mathrm{z} 377[M+\mathrm{H}]^{+}, 399[M+\mathrm{Na}]^{+}, 775[2 M+\mathrm{Na}]^{+}, 776[2 M+\mathrm{Na}+\mathrm{H}]^{+}$; Anal. calcd for $\mathrm{C}_{17} \mathrm{H}_{10} \mathrm{~F}_{2} \mathrm{~N}_{2} \mathrm{~S}_{3}$ : C 54.24, H 2.68, N 7.44, S 25.55, found: C 54.19, H 3.01, N 7.49, S 25.45 .

\section{Subcloning, protein expression, and purification}

The expression and purification of the catalytic domain of human PDE7A1 (residues 130-482) has been previously described.[36] Briefly, the PDE7A1 was subcloned into vector pET-32a and transferred into $E$. coli strain BL21 (codonplus). The $E$. coli culture carrying pET-PDE7A1 was grown in $2 \times \mathrm{YT}$ medium at $37^{\circ} \mathrm{C}$ to absorption $\mathrm{A}_{600}=1.0$ and then $0.1 \mathrm{~m}$ isopropyl- $\beta$-Dthiogalactopyranoside was added for further growth at $15^{\circ} \mathrm{C}$ for $12-16 \mathrm{~h}$. The catalytic domain of PDE7A1 was passed through a Ni-NTA column (Qiagen), subjected to thrombin cleavage, and further purified with Q-Sepharose (Amersham Biosciences) and Sephacryl S300 (Amersham Biosciences) columns. A typical batch of purification yielded $\sim 5 \mathrm{mg}$ PDE7A1 
from $4 \mathrm{~L}$ cell culture. Purified protein showed a single band in SDS-PAGE and native PAGE, and is estimated to have $>95 \%$ purity.

\section{Phosphodiesterase inhibition assay}

The catalytic domain of PDE7A1 (130-482) and full-length PDE4D2 (1-507) were subcloned into pET vectors, overexpressed in E. coli strain BL21, and purified to homogeneity, as previously reported.[36] The enzymatic activities of PDE7A1 and PDE4D2 were assayed by incubating the enzymes with $100 \mu \mathrm{L}$ reaction mixture of $20 \mathrm{~m}_{\mathrm{M}} \mathrm{Tris} \cdot \mathrm{HCl}(\mathrm{pH} 7.5), 10 \mathrm{~m}_{\mathrm{m}}$ $\mathrm{MgCl}_{2}, 1 \mathrm{~m}_{\mathrm{M}} \mathrm{DTT}$, and $\left[{ }^{3} \mathrm{H}\right] \mathrm{cAMP}$ (20 $000 \mathrm{cpm}$ per assay, Sigma-Aldrich) at RT for $15 \mathrm{~min}$. The reactions were terminated by addition of $200 \mu \mathrm{L} 0.2 \mathrm{M} \mathrm{ZnSO}_{4}$ when $20-50 \%$ of cAMP was hydrolyzed. The reaction product $\left[{ }^{3} \mathrm{H}\right] \mathrm{AMP}$ was precipitated by addition of $200 \mu \mathrm{L} 0.12 \mathrm{M} \mathrm{Ba}$ $(\mathrm{OH})_{2}$ (Sigma-Aldrich), whereas unreacted $\left[{ }^{3} \mathrm{H}\right]$ cAMP remained in the supernatant.

Radioactivity of the supernatant was measured in liquid scintillation cocktail (ScintiSafe Plus $^{\mathrm{TM}} 30 \%$, Fisher Scientific) with an LKB Rack-Beta 1214 counter. For measurement of inhibition, six to eight different inhibitor concentrations were used with a substrate concentration one tenth of the $K_{\mathrm{M}}$ value, and the suitable enzyme concentration. Each measurement was repeated twice. The $\mathrm{IC}_{50}$ values were defined as the compound concentration that effects $50 \%$ inhibition of the enzyme activity.

\section{Cell viability assays}

The effect of PDE4, PDE7, and dual inhibitors on T-cell viability was determined by propidium iodide $(\mathrm{PI})$ cell staining assays using the murine T-cell line D10.G4.1. Cells $\left(1 \times 10^{5}\right)$ were cultured in Click medium[45] in the presence of various concentrations of each inhibitor for $48 \mathrm{~h}$. Samples were collected and washed twice in PBS before treatment with PI $\left(5 \mu \mathrm{gmL}^{-1}\right)$ in a final volume of $0.5 \mathrm{~mL}$. Viable cells were identified by PI dye exclusion using a Becton Dickinson FACs Canto flow cytometer. The number of events collected for each sample in each series was the same (20000-50000).

\section{cAMP measurements}

D10.G4.1 cells were stimulated for $1 \mathrm{~h}$ with ionomycin and PMA in 96-well plates $\left(5 \times 10^{4}\right.$ cells per well), in the presence or absence of PDE inhibitors $\left(200 \mu_{\mathrm{M}}\right)$ or vehicle (DMSO). Intracellular cAMP was determined by a competitive enzyme immunoassay (EIA) system (Amersham, GE Healthcare).

\section{Nitrite production}

Raw 264.7 cells in a 96-well plate were treated or untreated for $1 \mathrm{~h}$ with various PDE inhibitors $\left(10 \mu_{\mathrm{M}}\right)$ and then stimulated with $10 \mu \mathrm{g} \mathrm{mL} \mathrm{L}^{-1}$ of LPS for $24 \mathrm{~h}$. The culture supernatants (50 $\mu \mathrm{L}$ ) were transferred to a 96-well assay plate, mixed with $50 \mu \mathrm{L}$ of Griess reagent, and incubated for $15 \mathrm{~min}$ at RT. The absorbance $(520 \mathrm{~nm})$ of the mixture was measured on a microplate reader.

\section{Crystallization and structure determination}

Crystals of PDE7A1-15 were grown by hanging drop at $4^{\circ} \mathrm{C}$. The catalytic domain of $5 \mathrm{mg}$ $\mathrm{mL}^{-1}$ PDE7A1 (amino acids 130-482) in a storage buffer of $50 \mathrm{~m}_{\mathrm{M}} \mathrm{NaCl}, 20 \mathrm{~m}_{\mathrm{M}}$ Tris. $\mathrm{HCl}(\mathrm{pH}$ 7.5), $1 \mathrm{~m}_{\mathrm{M}} \beta$-mercaptoethanol, and $1 \mathrm{~m}_{\mathrm{M}}$ EDTA was mixed with $1 \mathrm{~m}_{\mathrm{M}} \mathbf{1 5}$. The protein drops contained $2 \mu \mathrm{L}$ PDE7A1-15 and $2 \mu \mathrm{L}$ well buffer of 0.6-0.8м $\left(\mathrm{NH}_{4}\right)_{2} \mathrm{SO}_{4}, 2.5-5$ mм $\beta$ mercaptoethanol, $10 \mathrm{~m}_{\mathrm{M}}$ EDTA, 0.1 $\mathrm{M}$ Tris $\cdot \mathrm{HCl}, \mathrm{pH}$ 7.5. Diffraction data were collected on beamline X29 of the National Synchrotron Light Source (Table 5). The PDE7A1-15 crystal had the space group $P 3_{1} 21$ with cell dimensions of $a=b=115.4$, and $c=64.4 \AA$ The diffraction data were processed by the program HKL.[46] The structure of PDE7A1-15 was solved by molecular replacement program AMoRe,[47] using PDE7A1-IBMX[36] as the initial model. 
The atomic model was rebuilt by program O[48] against the electron density map that was improved by the density modification package of CCP4. The structure was refined by CNS. [49]

The coordinates and structural factors have been deposited into the Protein Data Bank with the accession code $3 \mathrm{G} 3 \mathrm{~N}$.

\section{Molecular modeling}

Docking was performed with the program rDock, which is an extension of the program RiboDock,[50] using an empirical scoring function calibrated on the basis of protein-ligand complexes.[51] This program uses an empirical scoring function for attractive and repulsive polar interactions in combination with a Lennard-Jones potential to define the van der Waals term. Ligand internal energies used the same terms as the intermolecular potential, plus a dihedral potential derived from the Tripos force field. A full search on ligand poses was performed using a genetic algorithm, in which a conventional chromosome representation of translation, rotation, and rotatable bond dihedral angles was used, while the receptor site was kept fixed. The reliability of rDock was assessed by docking eight PDE4 inhibitors, which were selected on the basis of their structural resemblance to the compounds (see Supporting Information). Thus, all of them are neutral and possess at least two rings, which may or may not be fused. Moreover, superposition of the X-ray crystallographic structures of the ligandPDE4 complexes confirmed unambiguously the structural similarity of the ligand binding sites. Water molecules were removed from the coordinates, and the docking volume was defined as the space within $10 \AA$ of the ligands in the binding site. Before docking, the structure of the ligands was built up and energy minimized at the MP2/6-31G* level using Gaussian 03.[52] Each compound was subjected to 100 docking runs, and the output docking modes were analyzed by visual inspection in conjunction with the docking scores.

MM/PBSA calculations were performed using the program AMBER.[53] The partial atomic charges for the compounds were derived using the RESP protocol[54] by fitting to the molecular electrostatic potential calculated at the $\mathrm{HF} / 6-31 \mathrm{G}^{*}$ level with Gaussian 03. Prior to MM/PBSA calculations, the inhibitor and the side chains of those residues pertaining to the binding site (see above) were energetically minimized. The electrostatic contribution ( $\left.\Delta G_{\text {ele }}\right)$ to the total free energy of binding ( $\Delta G_{\text {bind }}$ ) was determined using a dielectric constant of 80 for the aqueous environment, whereas values of 2 or 4 were considered for the ligand-receptor complex. The electrostatic potentials were calculated using a grid spacing of $0.25 \AA$. The interior of the solutes was defined as the volume inaccessible to a solvent probe sphere of radius 1.4 ̊. The nonpolar contribution $\left(\Delta G_{\mathrm{SAS}}\right)$ of the free energy was calculated using a linear dependence with the solvent-accessible surface $\left(0.025 \mathrm{kcal} \mathrm{mol}^{-1} \AA^{2}\right)$. The van der Waals interaction energy between ligand and protein $\left(\Delta G_{\mathrm{vdW}}\right)$ was determined using the standard formalism and parameters implemented in AMBER. The relative internal conformational energy $\left(\Delta G_{\text {int }}\right)$ of the receptor-ligand complexes was determined using the AMBER force field and considered when comparing the two binding modes of the ligand. Finally, entropy changes upon complex formation were assumed to be very similar in the two binding modes and therefore would cancel out in the comparison of the relative binding affinities.

$$
\Delta G_{\mathrm{bind}}=\Delta G_{\mathrm{ele}}+\Delta G_{\mathrm{vdW}}+\Delta G_{\mathrm{SAS}}+\Delta G_{\mathrm{int}}
$$




\section{Acknowledgments}

The authors gratefully acknowledge financial support for this project from Fundación de Investigación Médica Mutua Madrileña, Instituto de Salud Carlos III (FISPI06012/MPY 1281) and NIH grant GM59791 to H.K.; T.C. and O.H. acknowledge predoctoral fellowships from the Spanish Ministry of Education and Science.

\section{References}

1. Conti M, Beavo J. Annu. Rev. Biochem 2007;76:481-511. [PubMed: 17376027]

2. Essayan DM. Biochem. Pharmacol 1999;57:965-973. [PubMed: 10796066]

3. Allison AC. Immunopharmacology 2000;47:63-83. [PubMed: 10878284]

4. Lugnier C. Pharmacol. Ther 2006;109:366-398. [PubMed: 16102838]

5. Dyke HJ, Montana JG. Expert Opin. Invest. Drugs 2002;11:1-13.

6. Spina D. Drugs 2003;63:2575-2594. [PubMed: 14636078]

7. Menniti FS, Faraci WS, Schmidt CJ. Nat. Rev. Drug Discovery 2006;5:660-670.

8. Ekholm D, Hemmer B, Gao G, Vergelli M, Martin R, Manganiello V. J. Immunol 1997;159:15201529. [PubMed: 9233651]

9. Erdogan S, Houslay MD. Biochem. J 1997;321:165-175. [PubMed: 9003416]

10. Giembycz MA, Corrigan CJ, Seybold J, Newton R, Barnes PJ. Br. J. Pharmacol 1996;118:19451958. [PubMed: 8864528]

11. Manning CD, Burman M, Christensen SB, Cieslinski LB, Essayan DM, Grous M, Torphy TJ, Barnette MS. Br. J. Pharmacol 1999;128:1393-1398. [PubMed: 10602317]

12. Houslay MD, Schafer P, Zhang KYJ. Drug Discovery Today 2005;10:1503-1519. [PubMed: 16257373]

13. Chung K. Eur. J. Pharmacol 2006;533:110-117. [PubMed: 16458289]

14. Giembycz MA. Curr. Opin. Pharmacol 2005;5:238-244. [PubMed: 15907909]

15. Li L, Yee C, Beavo JA. Science 1999;283:848-851. [PubMed: 9933169]

16. Nakata A, Ogawa K, Sasaki T, Koyama N, Wada K, Kotera J, Kikkawa H, Omori K, Kaminuma O. Clin. Exp. Immunol 2002;128:460-466. [PubMed: 12067300]

17. Yang G, McIntyre KW, Townsend RM, Shen HH, Pitts WJ, Dodd JH, Nadler SG, McKinnon M, Watson AJ. J. Immunol 2003;171:6414-6420. [PubMed: 14662840]

18. Castro A, Jerez MJ, Gil C, Martínez A. Med. Res. Rev 2005;25:229-244. [PubMed: 15514991]

19. Martínez A, Castro A, Gil C, Miralpeix M, Segarra V, Doménech T, Beleta J, Palacios J, Ryder H, Miró X, Bonet C, Casacuberta J, Azorín F, Piña B, Puigdoménech P. J. Med. Chem 2000;43:683689. [PubMed: 10691694]

20. Castro A, Abasolo MI, Gil C, Segarra V, Martinez A. Eur. J. Med. Chem 2001;36:333-338. [PubMed: 11461758]

21. Vergne F, Bernardelli P, Chevalier E. Annu. Rep. Med. Chem 2005;40:227-241.

22. Giembycz MA, Smith SJ. Drugs Future 2006;31:207-229.

23. Gil C, Campillo NE, Perez DI, Martinez A. Expert Opin. Ther. Pat 2008;18:1127-1139.

24. Smith SJ, Cieslinski LB, Newton R, Donnelly LE, Fenwick PS, Nicholson AG, Barnes PJ, Barnette MS, Giembycz MA. Mol. Pharmacol 2004;66:1679-1689. [PubMed: 15371556]

25. Hatzelmann, A.; Marx, D.; Steinhilber, W. WO 02085906. 2002.

26. Pitts, WJ.; Watson, AJ.; Dodd, JH. WO 02088079. 2002.

27. Vijayakrishnan L, Rudra S, Eapen MS, Dastidar S, Ray A. Expert Opin. Invest. Drugs 2007;16:15851599.

28. Yamamoto S, Sugahara S, Naito R, Ichikawa A, Ikeda K, Yamada T, Shimizu Y. Eur. J. Pharmacol 2006;541:106-114. [PubMed: 16780833]

29. Jerez MJ, Gil C, Calderon F, Doménech T, Nueda A, Martínez A. Eur. J. Med. Chem 2008;43:13491359. [PubMed: 18082290]

30. Satpanthi PS, Trivedi JP. J. Indian Chem. Soc 1971;48:1021-1026.

31. Scheibye S, El-Barbary AA, Lawesson S-O. Tetrahedron 1982;38:3753-3760. 
32. Jesberger M, Davis TP, Barner L. Synthesis 2003:1929-1958.

33. Wang P, Wu P, Egan RW, Billah MM. Biochem. Biophys. Res. Commun 2000;276:1271-1277. [PubMed: 11027622]

34. Bloom TJ, Beavo JA. Proc. Natl. Acad. Sci. USA 1996;93:14188-14192. [PubMed: 8943082]

35. Guerra A, Paez JA, Campillo NE. QSAR Comb. Sci 2008;27:586-594.

36. Wang HC, Liu YD, Chen YX, Robinson H, Ke HM. J. Biol. Chem 2005;280:30949-30955. [PubMed: 15994308]

37. Ke H, Wang H. Curr. Top. Med. Chem 2007;7:391-403. [PubMed: 17305581]

38. Camps P, El Achab R, Gorbig DM, Morral J, Munoz-Torrero D, Badia A, Banos JE, Vivas NM, Barril X, Orozco M, Luque FJ. J. Med. Chem 1999;42:3227-3242. [PubMed: 10464010]

39. Foloppe N, Fisher LM, Howes R, Kierstan P, Potter A, Robertson AGS, Surgenor AE. J. Med. Chem 2005;48:4332-4345. [PubMed: 15974586]

40. Lyne PD, Lamb ML, Saeh JC. J. Med. Chem 2006;49:4805-4808. [PubMed: 16884290]

41. Weis A, Katebzadeh K, Soderhjelm P, Nilsson I, Ryde U. J. Med. Chem 2006;49:6596-6606. [PubMed: 17064078]

42. El-Sharief AMS, Ammar YA, Mohamed YA, El-Gaby MSA. Heteroat. Chem 2002;13:291-298.

43. Alagarsamy V, Giridhar R, Yadav MR. Bioorg. Med. Chem. Lett 2005;15:1877-1880. [PubMed: 15780625]

44. Wagner G, Rothe L. Pharmazie 1971;26:459-461. [PubMed: 5122930]

45. Peck AB, Bach FH. J. Immunol. Methods 1973;3:147-163. [PubMed: 4271080]

46. Otwinowski Z, Minor W. Methods Enzymol 1997;276:307-326.

47. Navaza J, Saludjian P. Methods Enzymol 1997;276:581-594.

48. Jones TA, Zou JY, Cowan SW, Kjeldgaard M. Acta Crystallogr. Sect. A 1991;47:110-119. [PubMed: 2025413]

49. Brunger AT, Adams PD, Clore GM, DeLano WL, Gros P, Grosse-Kunstleve RW, Jiang JS, Kuszewski J, Nilges M, Pannu NS, Read RJ, Rice LM, Simonson T, Warren GL. Acta Crystallogr. Sect. D 1998;54:905-921. [PubMed: 9757107]

50. Morley SD, Afshar M. J. Comput. Aided Mol. Des 2004;18:189-208. [PubMed: 15368919]

51. Barril X, Hubbard RE, Morley SD. Mini Rev. Med. Chem 2004;4:779-791. [PubMed: 15379645]

52. Gaussian 03: Frisch, MJ.; Trucks, GW.; Schlegel, HB.; Scuseria, GE.; Robb, MA.; Cheeseman, JR.; Montgomery, JA., Jr; Vreven, T.; Kudin, KN.; Burant, JC.; Millam, JM.; Iyengar, SS.; Tomasi, J.; Barone, V.; Mennucci, B.; Cossi, M.; Scalmani, G.; Rega, N.; Petersson, GA.; Nakatsuji, H.; Hada, M.; Ehara, M.; Toyota, K.; Fukuda, R.; Hasegawa, J.; Ishida, M.; Nakajima, T.; Honda, Y.; Kitao, O.; Nakai, H.; Klene, M.; Li, X.; Knox, JE.; Hratchian, HP.; Cross, JB.; Bakken, V.; Adamo, C.; Jaramillo, J.; Gomperts, R.; Stratmann, RE.; Yazyev, O.; Austin, AJ.; Cammi, R.; Pomelli, C.; Ochterski, JW.; Ayala, PY.; Morokuma, K.; Voth, GA.; Salvador, P.; Dannenberg, JJ.; Zakrzewski, VG.; Dapprich, S.; Daniels, AD.; Strain, MC.; Farkas, O.; Malick, DK.; Rabuck, AD.; Raghavachari, K.; Foresman, JB.; Ortiz, JV.; Cui, Q.; Baboul, AG.; Clifford, S.; Cioslowski, J.; Stefanov, BB.; Liu, G.; Liashenko, A.; Piskorz, P.; Komaromi, I.; Martin, RL.; Fox, DJ.; Keith, T.; Al- Laham, MA.; Peng, CY.; Nanayakkara, A.; Challacombe, M.; Gill, PMW.; Johnson, B.; Chen, W.; Wong, MW.; Gonzalez, C.; Pople, JA. Wallingford, CT (USA): Gaussian Inc; 2004.

53. AMBER 8: Case, DA.; Darden, TA.; Cheatham, TE.; Simmerling, CL.; Wang, J.; Duke, RE.; Luo, R.; Merz, KM.; Wang, B.; Pearlman, DA.; Crowley, M.; Brozell, S.; Tsui, V.; Gohlke, H.; Mongan, J.; Hornak, V.; Cui, G.; Beroza, P.; Schafmeister, C.; Caldwell, JW.; Ross, WS.; Kollman, PA. San Francisco, CA (USA): University of California; 2000.

54. Bayly CI, Cieplak P, Cornell W, Kollman PA. J. Phys. Chem 1993;97:10269-10280. 

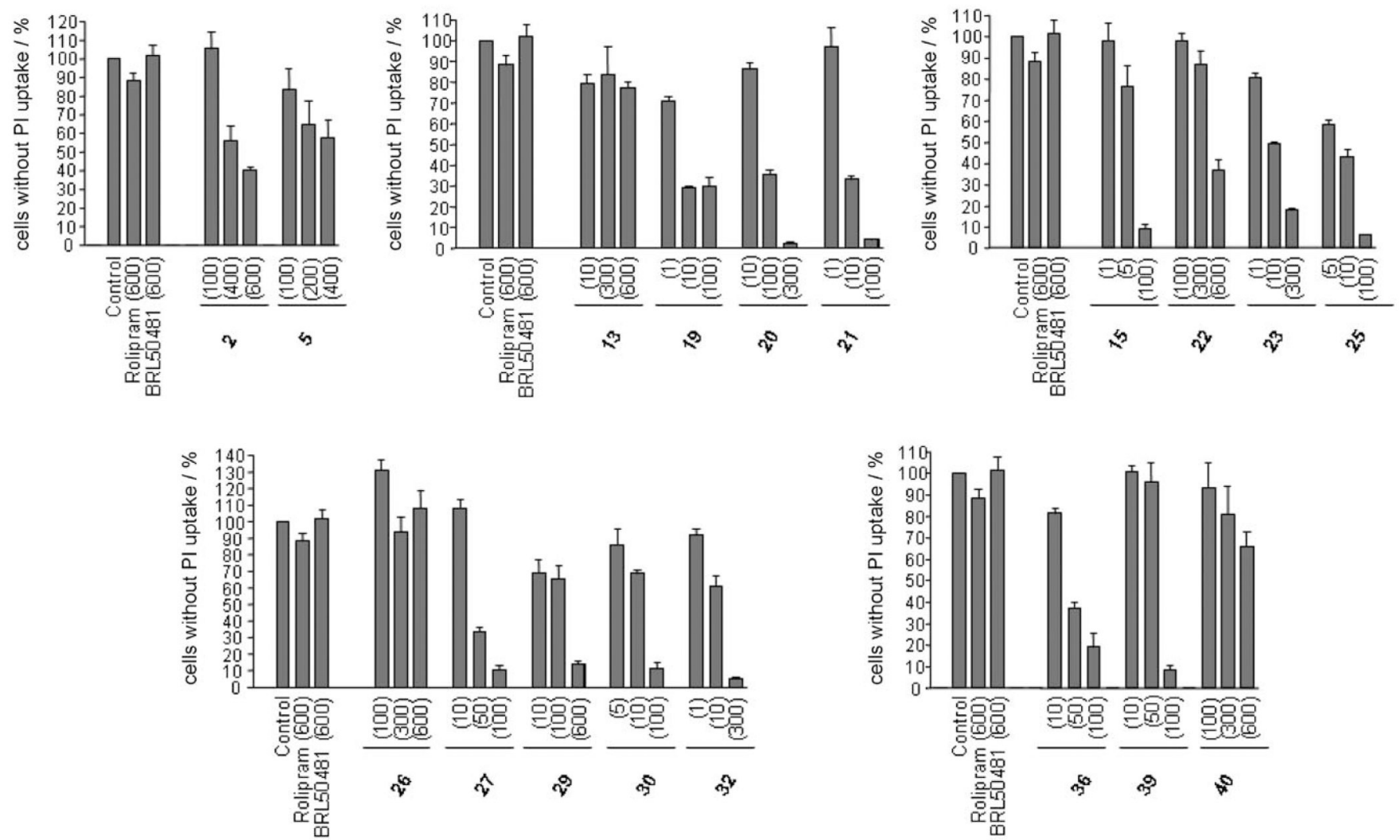

Figure 1.

Toxicity induced in D10.G4.1 cells by the PDE inhibitors. Each inhibitor concentration $\left(\mu_{\mathrm{M}}\right)$ is indicated in parentheses. Propidium iodide (PI) cell staining was measured by flow cytometry. Results are referenced to the value obtained for the control [without treatment with PDE inhibitor (100\%)]. The experiments for each PDE inhibitor at three concentrations were repeated at least twice; each value is shown as the mean \pm SEM. 
a)

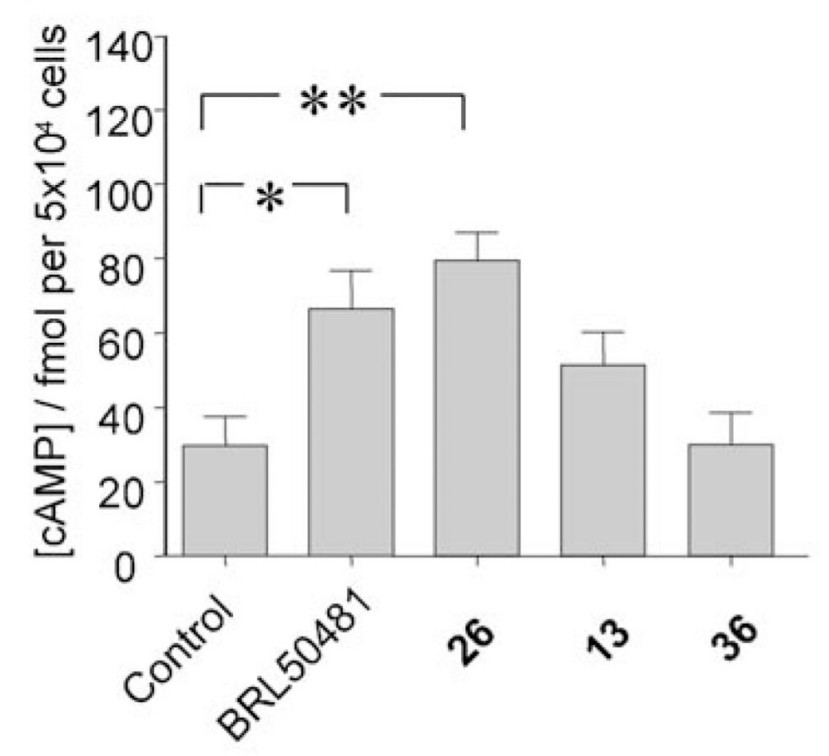

b)

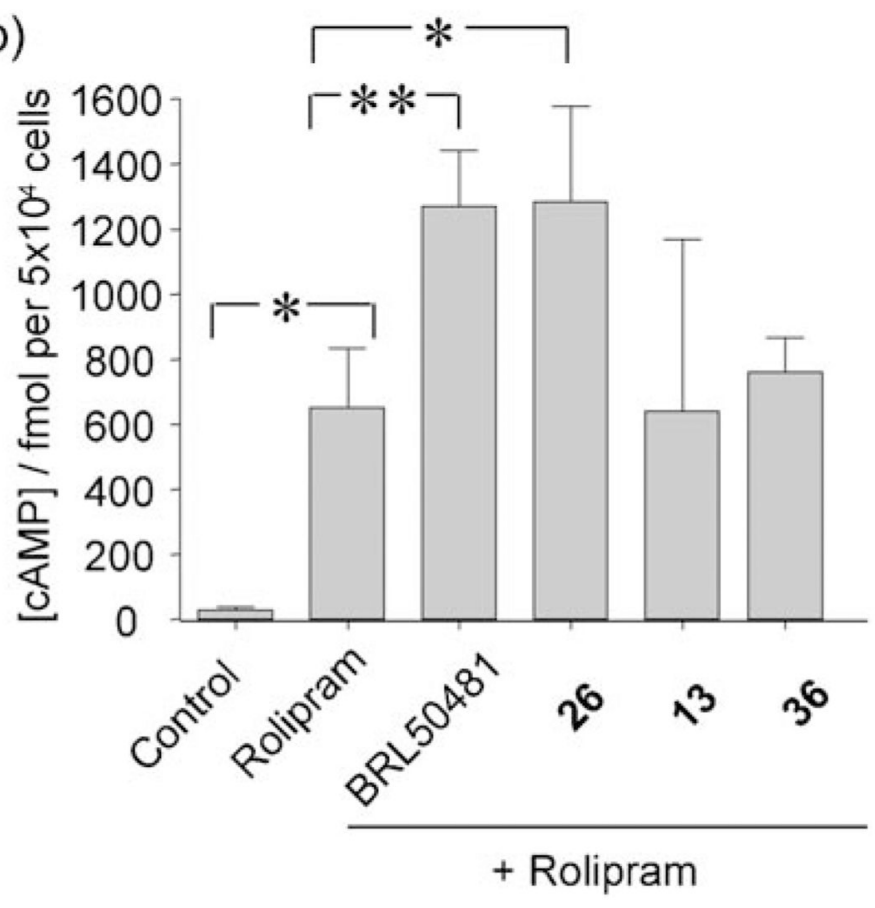

Figure 2.

Intracellular cAMP levels in D10.G4.1 cells treated with the indicated PDE inhibitor (200 $\mu_{\mathrm{M}}$ ). Values are presented as fmol cAMP in $5 \times 10^{4}$ cells. Data from the competitive enzyme immunoassay (EIA) system were exported to the GraphPad Prism software program to perform statistical analysis. The unpaired $t$-test with Welch's correction was used to analyze significant differences between the cAMP amount in the samples. *: $p<0.05, * *: p<0.01$. 


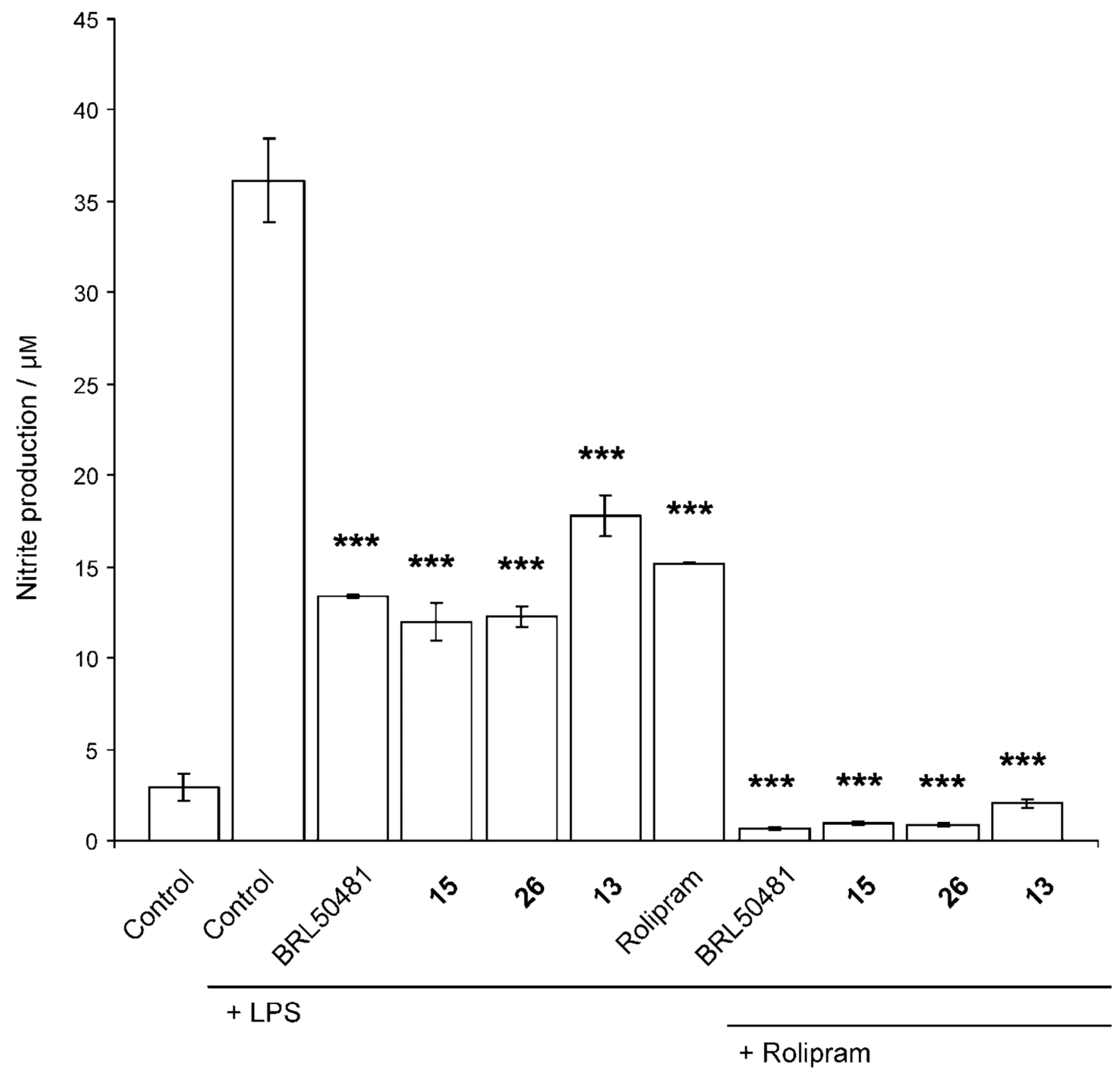

Figure 3.

Raw 264.7 cells were incubated for $24 \mathrm{~h}$ with lipopolysaccharide (LPS; $10 \mu \mathrm{g} \mathrm{mL}^{-1}$ ) in the absence or presence of various PDE inhibitors $\left(10 \mu_{\mathrm{M}}\right)$, and the production of nitrite was evaluated by the Griess reaction. Cells were pretreated with inhibitors for $1 \mathrm{~h}$ before LPS stimulation. Values represent the mean \pm SD from two independent experiments. ***: $p<0.001$ versus LPS-treated cells. 


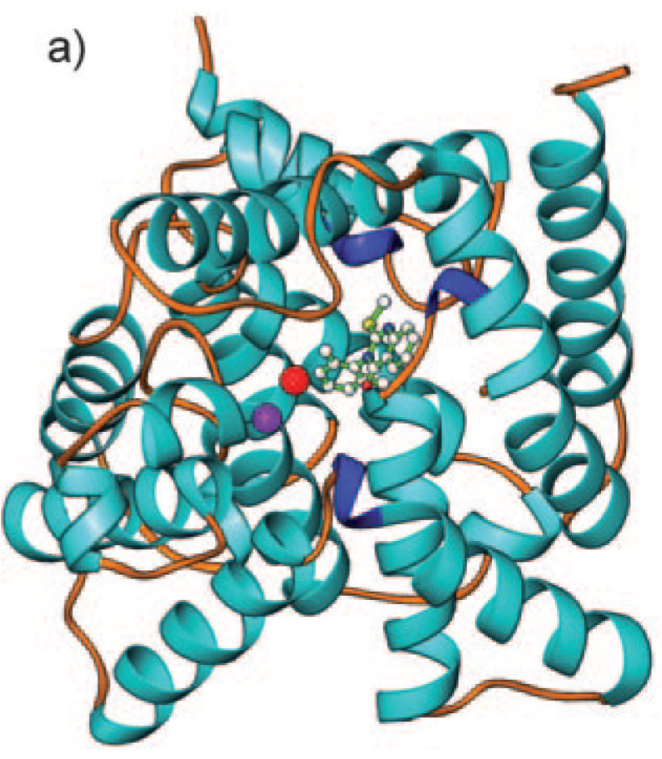

b)

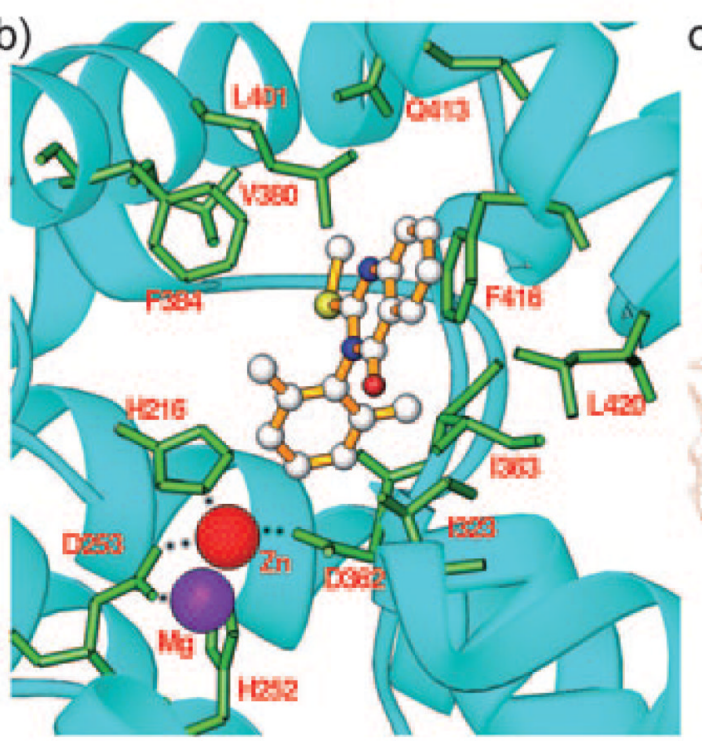

c)

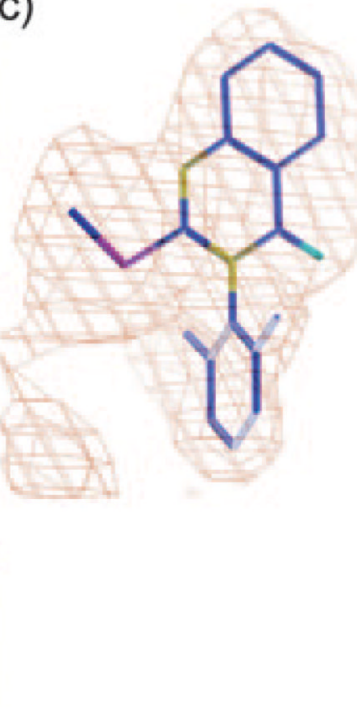

Figure 4.

Structure of the PDE7A1 catalytic domain. a) Ribbon diagram of the PDE7A1 catalytic domain. The red and purple balls represent zinc and magnesium ions, respectively. b) Binding of $\mathbf{1 5}$ at the active site of PDE7A1. c) Electron density for 15. The $\left(F_{\mathrm{o}}-F_{\mathrm{c}}\right)$ map was calculated from the structure with omission of the inhibitor $\mathbf{1 5}$. 

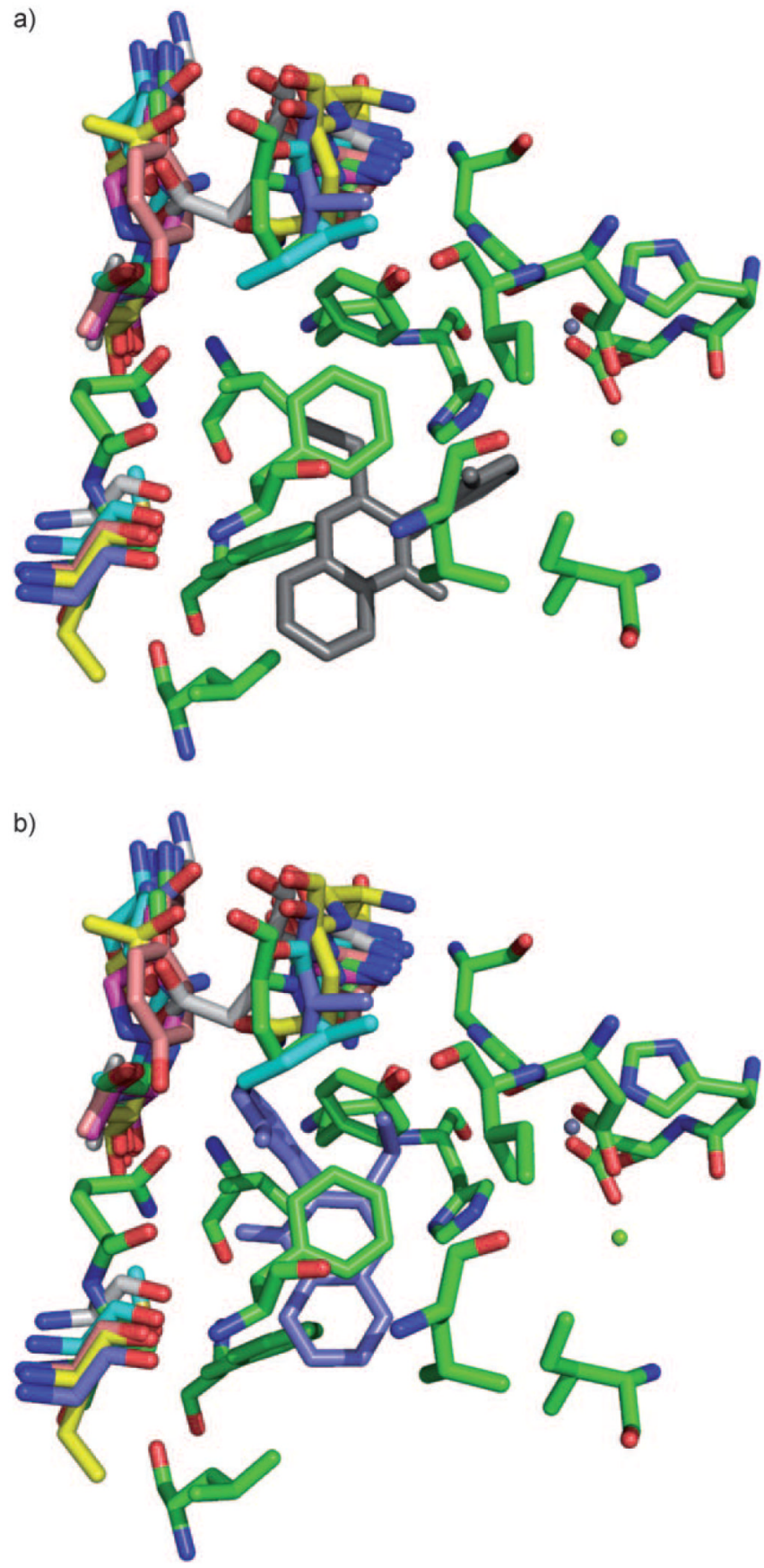

Figure 5.

Superimposition of the residues in the binding site of PDE2A, PDE3A, PDE4A, PDE5, PDE7A, PDE9, and PDE10A. For the sake of clarity, only those mutations that are not conserved relative to the composition of residues in the binding site of PDE7A1 are shown. a) Representation of the PDE7A1 binding site and of the nonconservative mutations with compound 15 in the X-ray crystallographic binding mode B (gray). b) Alternative pose of $\mathbf{1 5}$ (blue) in the PDE7A1 binding site found in docking studies, which enables hydrogen bonding with the invariant Gln413. 

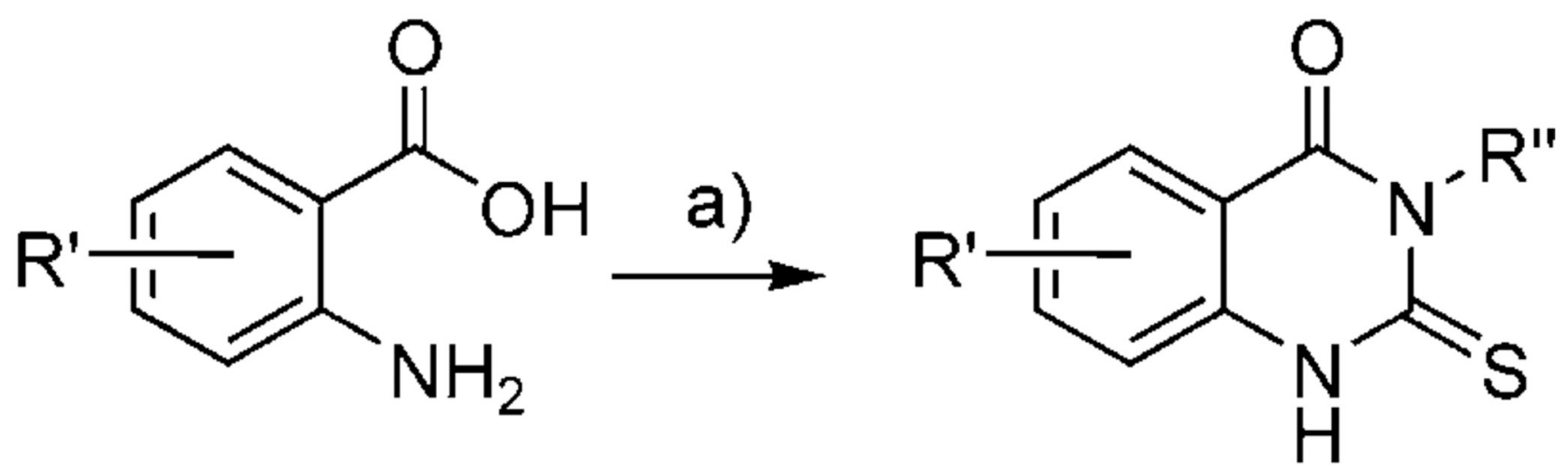

$$
\begin{array}{lll}
\mathrm{R}^{\prime}=6-\mathrm{Br} & \mathrm{R}^{\prime \prime}=\mathrm{Ph} & \mathbf{6} \\
\mathrm{R}^{\prime}=6-\mathrm{Br} & \mathrm{R}^{\prime \prime}=2,6-\operatorname{diF} P h & \mathbf{7} \\
\mathrm{R}^{\prime}=6-\mathrm{Br} & \mathrm{R}^{\prime \prime}=2,3,4-\operatorname{triFPh} & \mathbf{8} \\
\mathrm{R}^{\prime}=6-\mathrm{Br} & \mathrm{R}^{\prime \prime}=2-\mathrm{Br} \mathrm{Ph} & \mathbf{9}
\end{array}
$$

$\mathrm{R}^{\prime}=8-\mathrm{Me} \quad \mathrm{R}^{\prime \prime}=\mathrm{Ph}$

$R^{\prime}=8-M e \quad R^{\prime \prime}=2,6-d i F P h \quad 11$

$R^{\prime}=8-M e \quad R^{\prime \prime}=2,3,4-$ triFPh 12

$\mathrm{R}^{\prime}=8-\mathrm{Me} \quad \mathrm{R}^{\prime \prime}=2-\mathrm{BrPh} \quad 13$

Scheme 1.

Reagents and conditions: a) R"NCS, EtOH, $4^{\circ} \mathrm{C}$. 
<smiles>[R7]n1c(=S)[nH]c2ccccc2c1=S</smiles><smiles>[R][Y]1ccc2[nH]c(=S)n([R7])c(=O)c2c1</smiles><smiles>[R][X]c1ccc2nc(S[Y5])n([R7])c(=O)c2c1</smiles><smiles>[R]n1c(S[CH])nc2ccccc2c1=S</smiles>

$$
\begin{array}{ll}
R^{\prime \prime}=P h & 26 \\
R^{\prime \prime}=2,6-d i F P h & \mathbf{2 7} \\
R^{\prime \prime}=2,3,4-\text { triFPh } & \mathbf{2 8}
\end{array}
$$

$$
\begin{array}{llll}
2 & R^{\prime}=H & R^{\prime \prime}=P h & 14 \\
3 & R^{\prime}=H & R^{\prime \prime}=2,6-d i F P h & 15 \\
4 & R^{\prime}=H & R^{\prime \prime}=2,3,4-\operatorname{triFPh} & 16 \\
5 & R^{\prime}=H & R^{\prime \prime}=2-B r P h & 17
\end{array}
$$$$
15
$$

$\mathrm{R}^{\prime \prime}=\mathrm{Ph}$ 29

$\mathrm{R}^{\prime \prime}=\mathrm{Ph}$ 18

$6 \quad \mathrm{R}^{\prime}=6-\mathrm{Br}$

$\mathrm{R}^{\prime \prime}=2,6-\mathrm{diFPh}$

19

$8 R^{\prime}=6-B r$

$\mathrm{R}^{\prime \prime}=$ 2,3,4-triFPh

20

$9 \mathrm{R}^{\prime}=6-\mathrm{Br}$

$\mathrm{R}^{\prime \prime}=2-\mathrm{BrPh}$

$\mathrm{R}^{\prime \prime}=$ 2,6-diFPh

30

$\mathrm{R}^{\prime \prime}=$ 2,3,4-triFPh 31

$\mathrm{R}^{\prime \prime}=2-\mathrm{BrPh}$

$\begin{array}{llll}10 & R^{\prime}=8-M e & R^{\prime \prime}=\text { Ph } & 22 \\ 11 & R^{\prime}=8-M e & R^{\prime \prime}=2,6-d i F P h & 23 \\ 12 & R^{\prime}=8-M e & R^{\prime \prime}=2,3,4-t r i F P h & 24 \\ 13 & R^{\prime}=8-M e & R^{\prime \prime}=2-B r P h & 25\end{array}$

Scheme 2.

Reagents and conditions: a) MeI, $\mathrm{K}_{2} \mathrm{CO}_{3}$, DMF, RT; b) Lawesson's reagent, toluene, $\Delta$. 


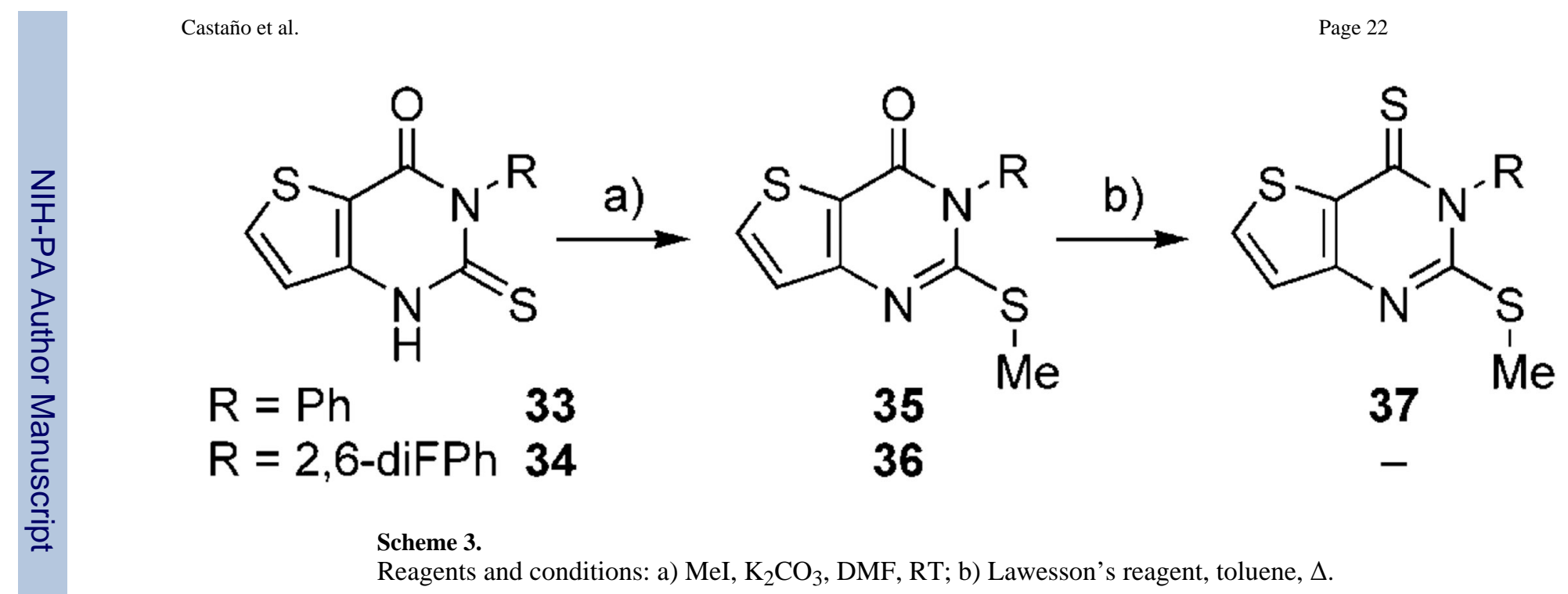


<smiles>[Y13]Sc1nc2c(sc3ccccc32)c(=O)n1[R]</smiles>

$\mathrm{R}=2,6-$ diFPh 38
39

Scheme 4.

Reagents and conditions: a) MeI, $\mathrm{K}_{2} \mathrm{CO}_{3}$, DMF, RT; b) Lawesson's reagent, toluene, $\Delta$. 
Table 1

Inhibition of PDE7A and PDE4B.

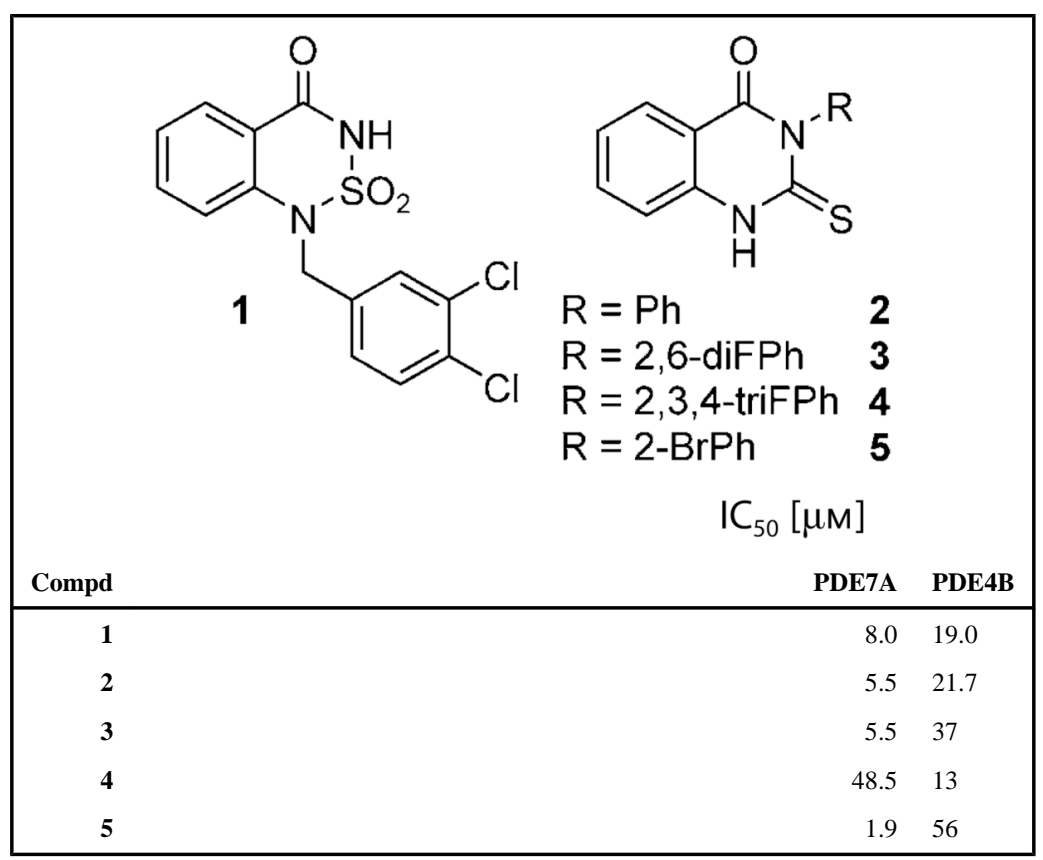




\section{Table 2}

Inhibition of PDE7A1 and PDE4D2.

\begin{tabular}{|c|c|c|}
\hline \multirow[b]{2}{*}{ Compd } & \multicolumn{2}{|c|}{$\mathrm{IC}_{50}[\boldsymbol{\mu} \mathrm{M}]$} \\
\hline & PDE7A1 & PDE4D2 $[a]$ \\
\hline IBMX & $8.1 \pm 0.4$ & 31 \\
\hline Rolipram & $129 \pm 10$ & $0.55 \pm 0.05$ \\
\hline 6 & $>10$ & ND \\
\hline 7 & $>10$ & ND \\
\hline 8 & $>10$ & ND \\
\hline 9 & $\sim 10$ & ND \\
\hline 11 & $>1$ & ND \\
\hline 12 & $>10$ & ND \\
\hline 13 & $1.7 \pm 0.1$ & $34 \pm 5$ \\
\hline 15 & $0.51 \pm 0.02$ & $3.5 \pm 0.3$ \\
\hline 16 & $\sim 10$ & ND \\
\hline 18 & $>1$ & ND \\
\hline 19 & $0.24 \pm 0.03$ & $4.5 \pm 0.1$ \\
\hline 20 & $2.1 \pm 0.1$ & ND \\
\hline 21 & $1.86 \pm 0.18$ & ND \\
\hline 22 & $\sim 1$ & ND \\
\hline 23 & $0.13 \pm 0.02$ & $1.4 \pm 0.2$ \\
\hline 24 & $>1$ & ND \\
\hline 25 & $0.27 \pm 0.02$ & $1.1 \pm 0.2$ \\
\hline 26 & $1.04 \pm 0.08$ & $5.70 \pm 0.03$ \\
\hline 27 & $\sim 1$ & ND \\
\hline 28 & $>1$ & ND \\
\hline 29 & $0.84 \pm 0.01$ & $8.0 \pm 1.2$ \\
\hline 30 & $0.1-1$ & ND \\
\hline 31 & $>1$ & ND \\
\hline 32 & $0.1-1$ & ND \\
\hline 35 & $\sim 10$ & ND \\
\hline 36 & $0.8 \pm 0.2$ & ND \\
\hline 39 & $0.41 \pm 0.03$ & $1.6 \pm 0.4$ \\
\hline 40 & $0.1-1$ & ND \\
\hline
\end{tabular}

${ }^{[a]} \mathrm{ND}$ : not determined. 


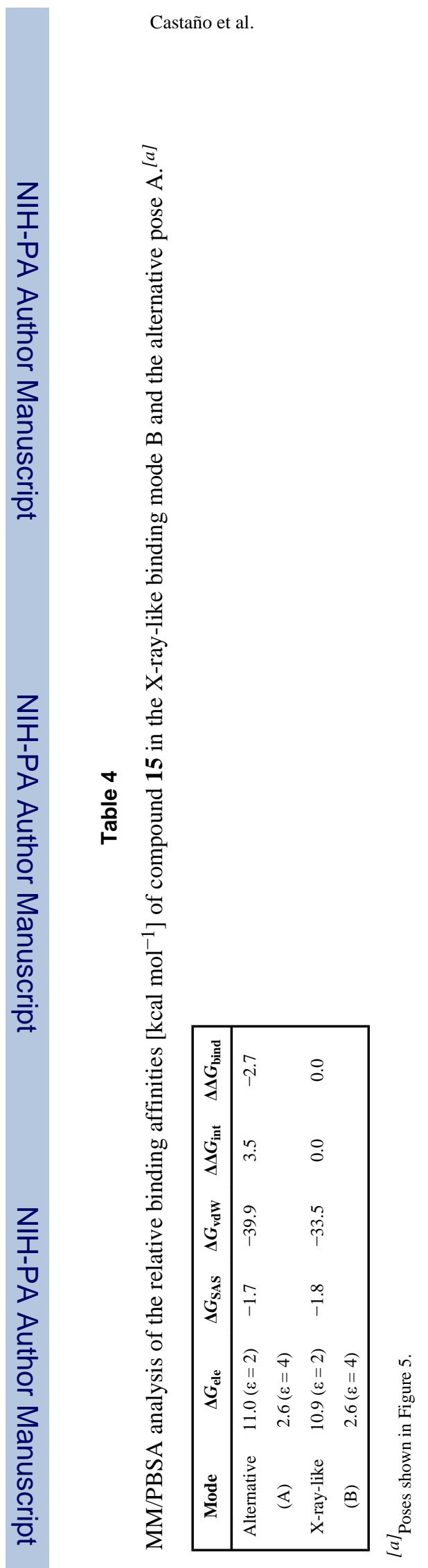

ChemMedChem. Author manuscript; available in PMC 2010 October 12. 
Table 5

Statistics on diffraction data and structure refinement.

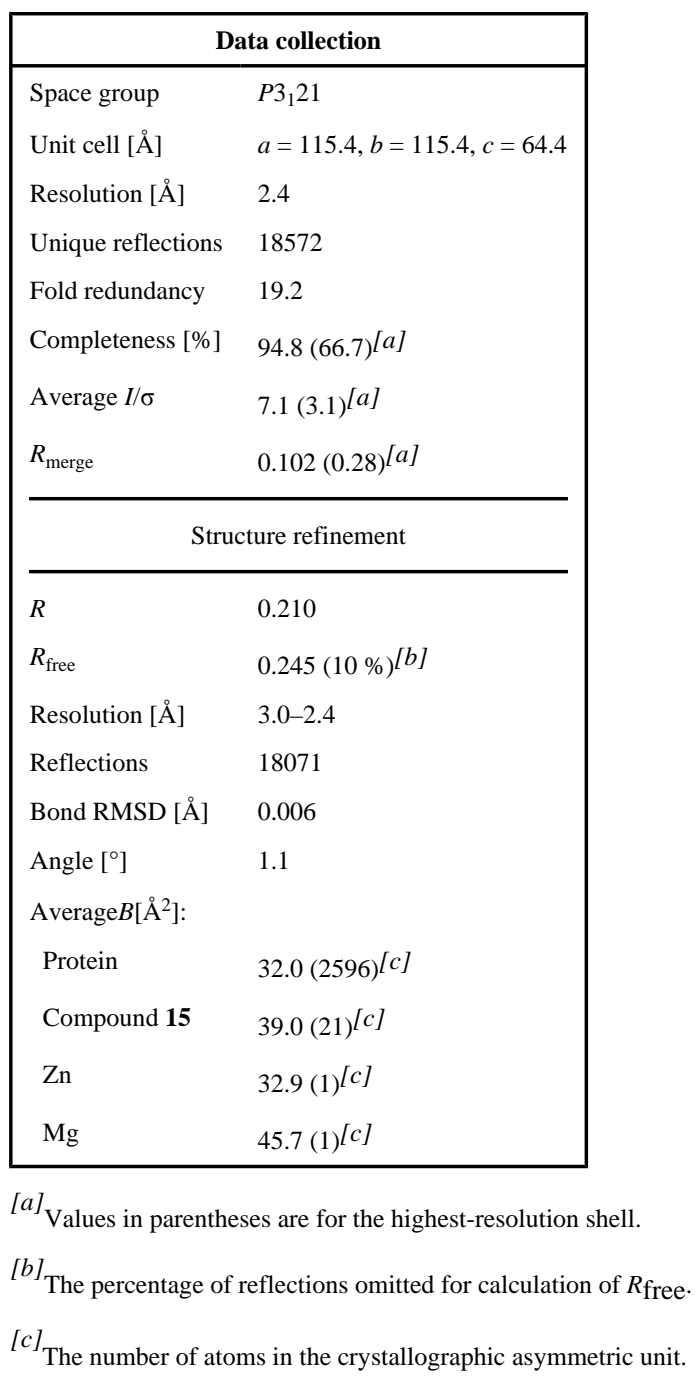

